\title{
THE RELATIONSHIP BETWEEN SELF-EFFICACY AND MENTAL HEALTH AMONG TEACHERS' SAMPLE AT AL-BATINAH NORTH GOVERNORATE THE SULTANATE OF OMAN
}

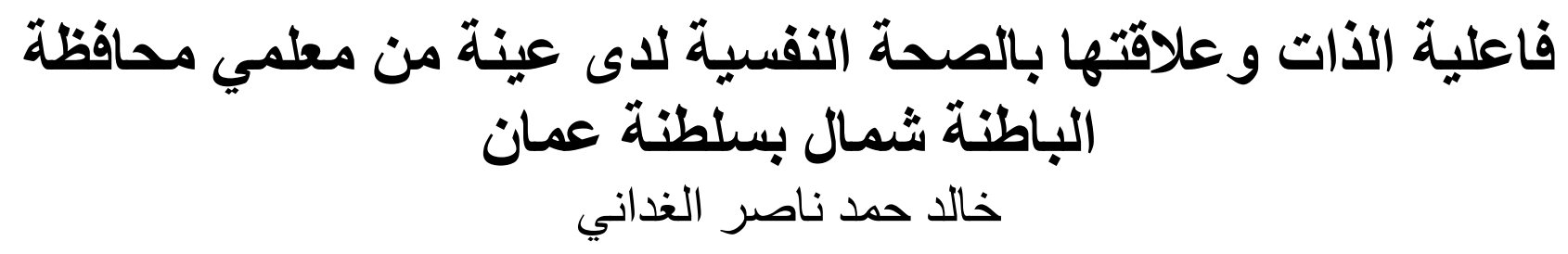

\author{
Khalid hamed Nasser AL Ghdani ${ }^{1 *} \&$ Nik Ahmad Hisham Ismail ${ }^{2}$ \\ ${ }^{1}$ Ph.D. Candidate at the Faculty of Education, International Islamic University Malaysia (IIUM), \\ alghani461@gmail.com \\ ${ }^{2}$ Prof. Dr., Faculty ofEducation, International Islamic University Malaysia (IIUM), \\ nikahmad@iium.edu.my \\ ${ }^{*}$ Corresponding Author
}

\begin{abstract}
This quantitative study discussed the relationship between self-efficacy and mental health among a sample of teachers from Al-Batinah north Governorate, at the Sultanate of Oman. The problem in the self- efficacy, which has become an important and vital requirement in the teachers' personality, in facing the challenges of rapid and successive developments, and to enable them to acquire the necessary skills in dealing with students and their daily problems. So, the study aims to determine the level of both self-efficacy and mental health, the correlation between them, and individual differences in the teachers' variables. The study followed the descriptive analytical method. A random sample of (100) teachers was selected. The study used the Self-Efficiency Scale (Abu Ghaly, 2012) consisting of (30) statements and the mental health scale (Ismail, 2016) consisting of ( 36) statements. The findings indicated that: the level of self-efficacy among the teachers was an intermediate level $(60.63 \%)$, the percentage of the level of mental health among the teachers reached $(62.02 \%)$ which is also an intermediate level. The Pearson correlation coefficient between self-efficacy and mental health was equal to (0.68), which is a positive correlation coefficient, which means that the relationship is direct, that is, the more self-efficacy increases, mental health increases. It concluded that there are no statistically significant differences for teachers in the level of self-efficacy and mental health attributable to the variables.
\end{abstract}

Keywords: self-efficacy, mental health, teachers.

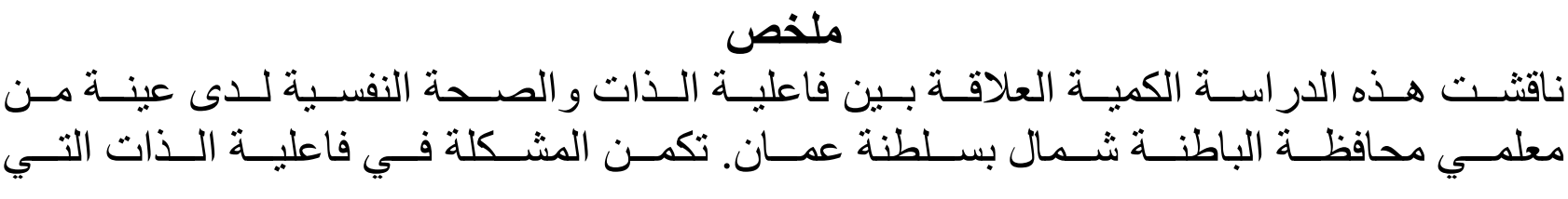




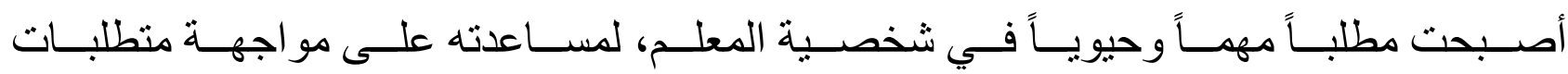

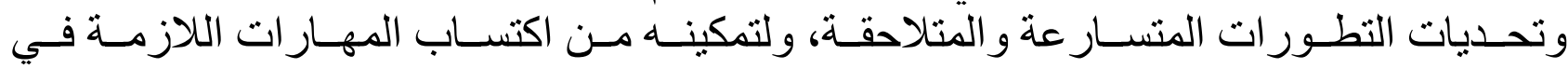

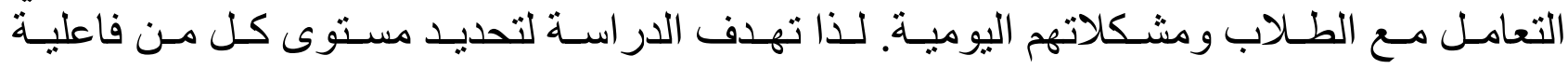

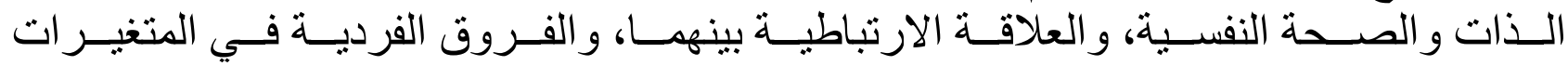

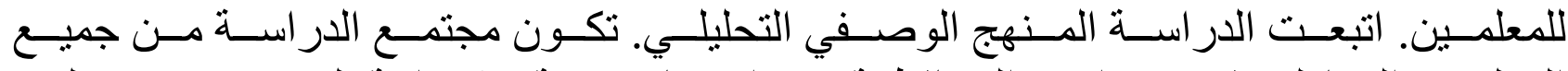

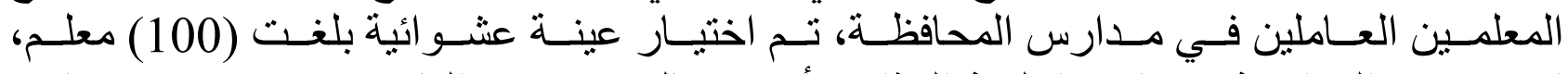

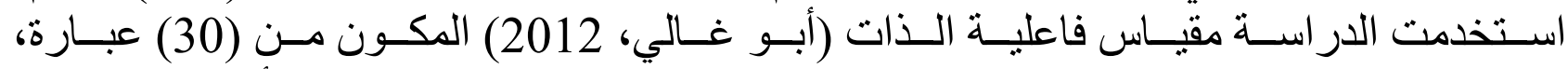

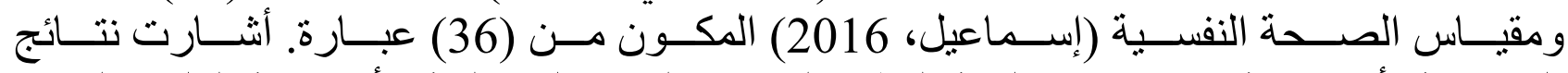

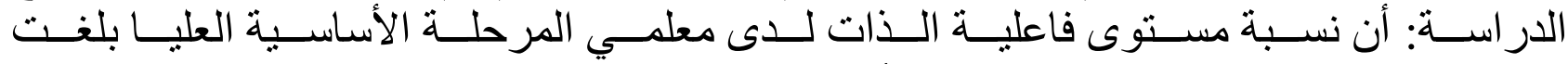

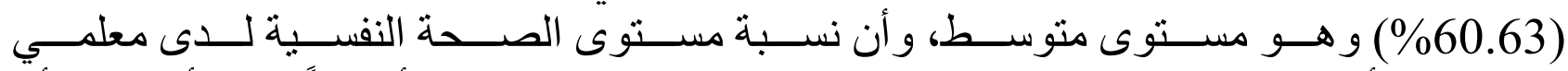

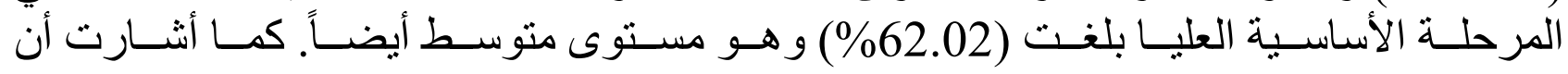

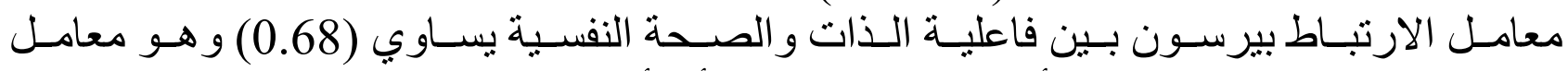

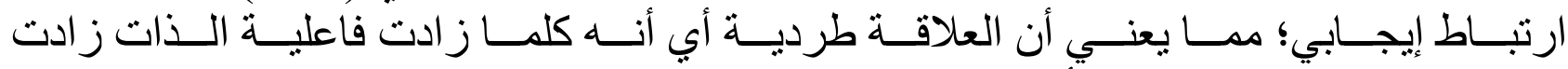

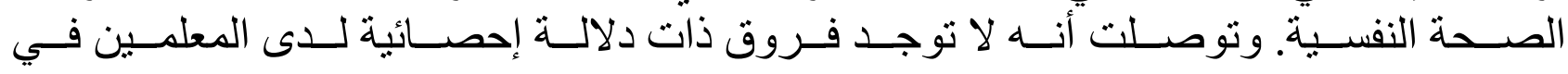

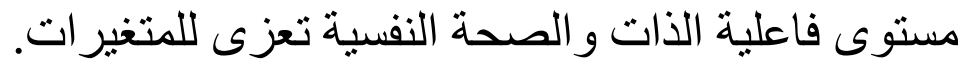
كلمات مفتاحية: فاعلية الذات، الصحة النفسية، المعلمين.

المقدمة: - مزئ

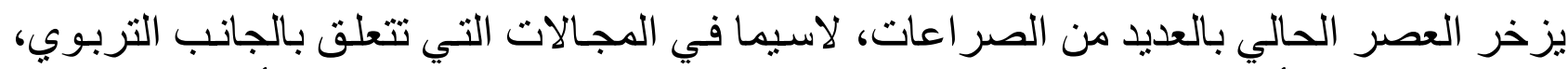

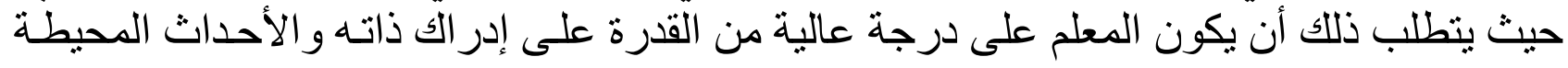

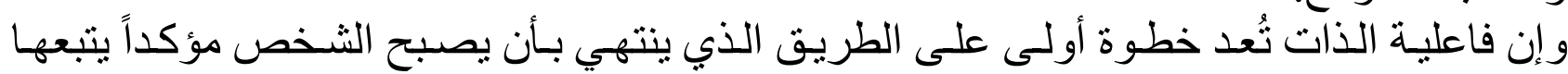

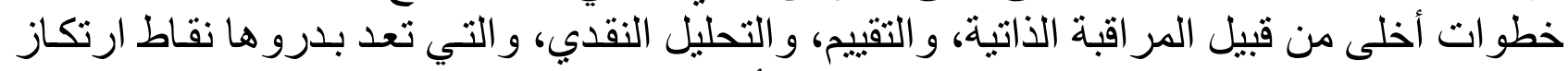

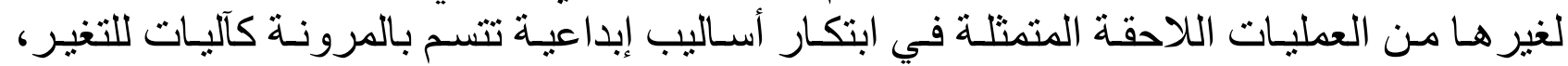

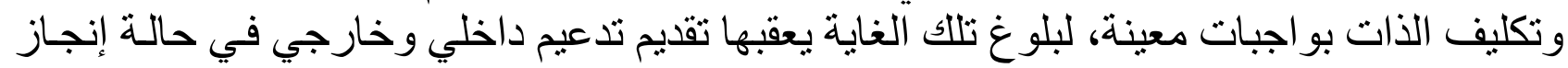

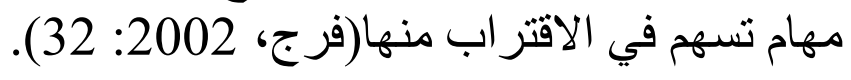

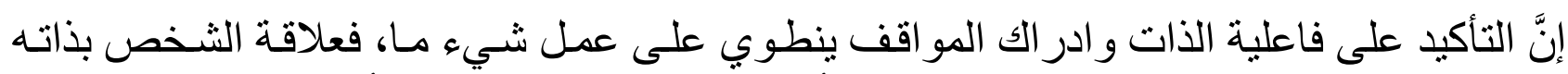

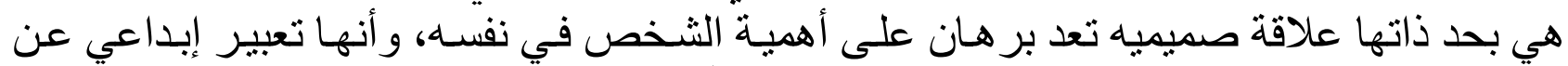

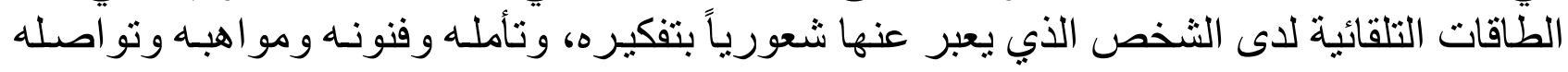

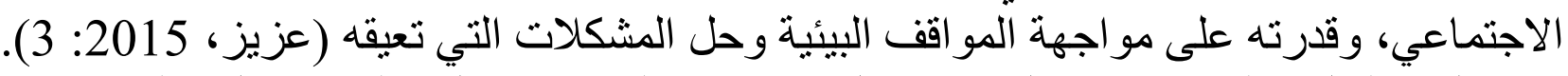

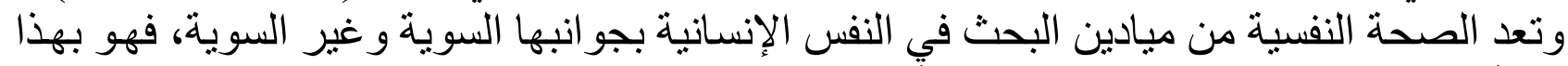

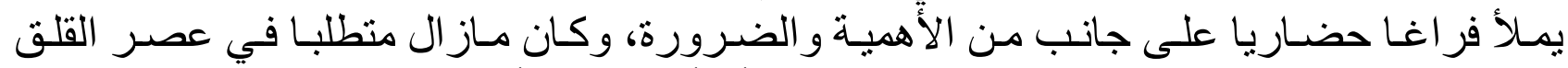

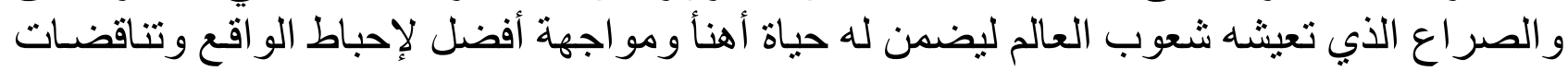

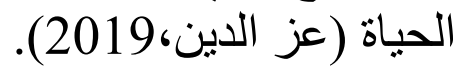


مشكلة الدراسة:

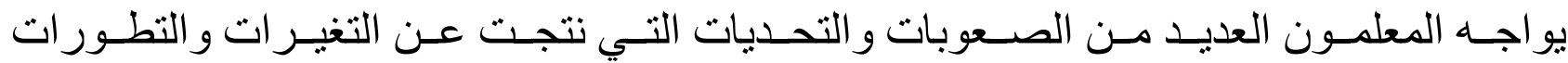

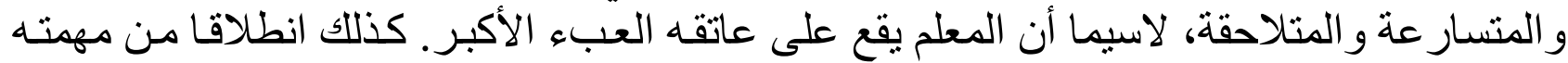

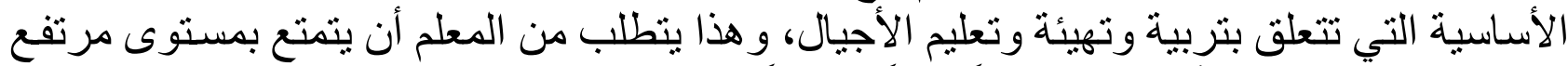

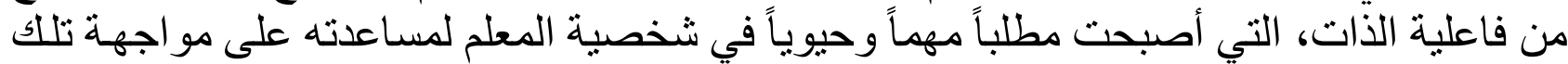

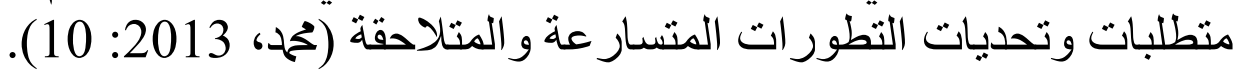

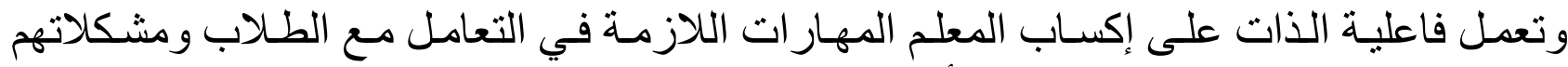

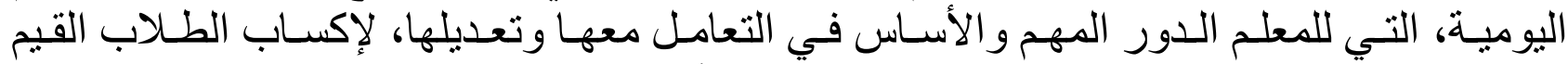

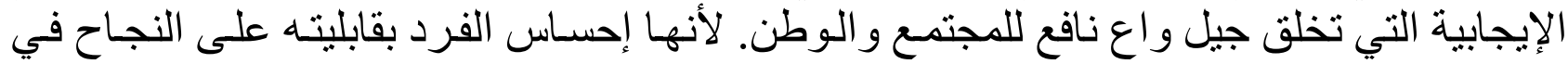

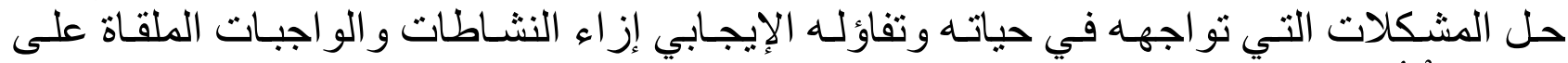

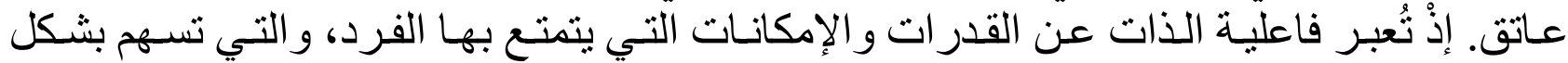
إيجابي في مو اجهة أحداث الحياة اليومية، وتعد ركيزة أساسية من ركائز التمتع بالصحان الصحة النفسية.

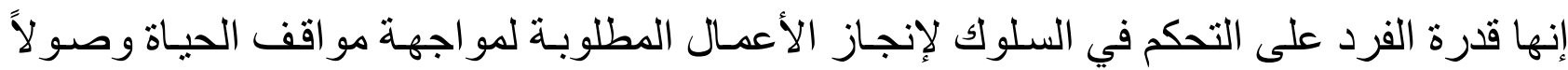

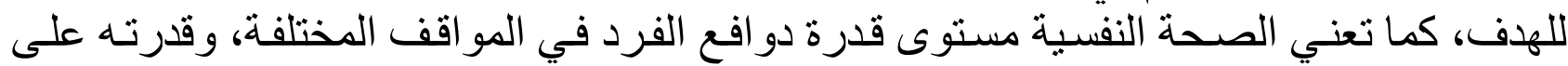

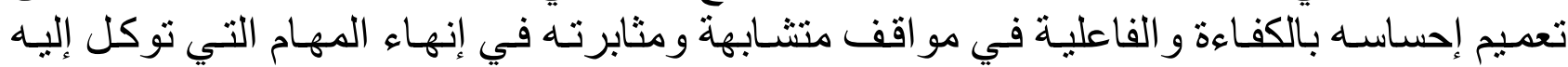

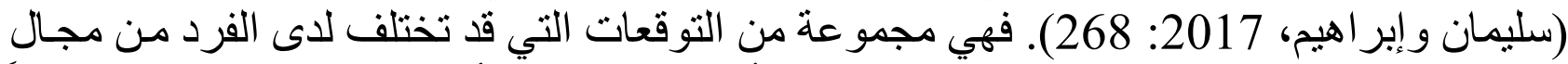

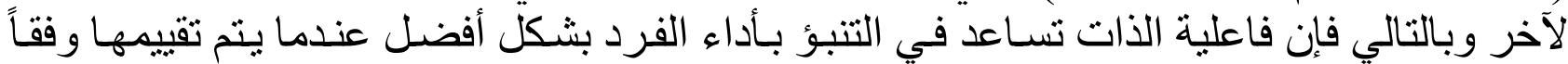

لمجالات محددة (5) : (Bandura, 2001).

و هذا يتطلب من المعلم أن يتمتع بمستوى جيد من الصحة النفسية، التي ترتبط ارتباطـا وثيقا بقدرة

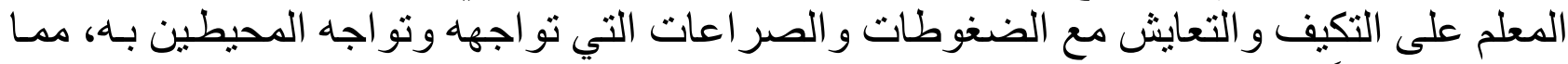
قد يسهم إيجابياً في تحسين الصحة النفسية لدى الطلاب كذلك.

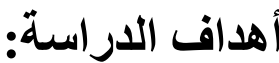

أ. تحديد مستوى فاعلية الذات لاى المعلمين في محافظة شمال الباطنة في سلطنة عمان. ب. تحديد مستوى الصحة النفسية لدى المعلمين في محافظة شمال الباطنة في سلطنة فئة عمان.

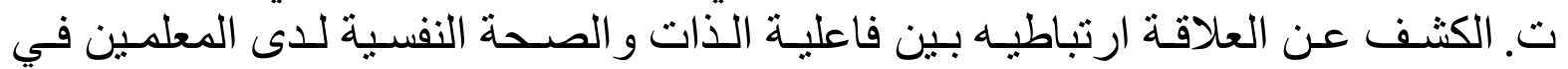
محافظة الباطنة شمال في سلطنة العات عمان.

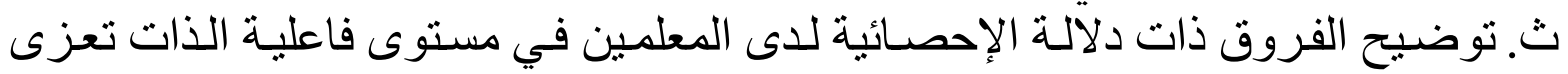

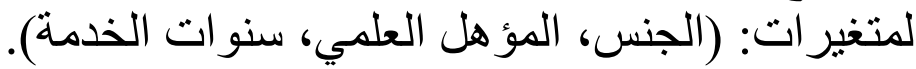

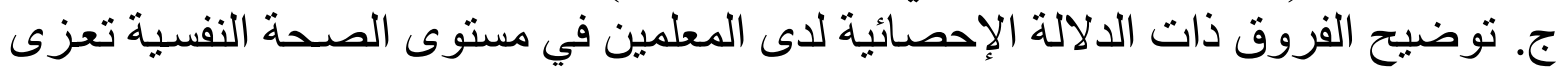

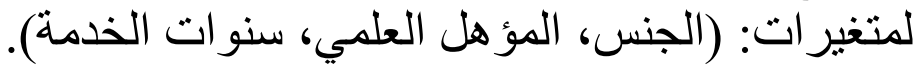

الإطار النظري: - (النظ:

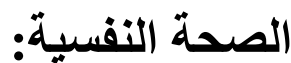
تعتبر صحة الإنسان النفسية من المظاهر الأساسية والمهمة في بنـاء شخصيته وطريقة تفاعله مـع 


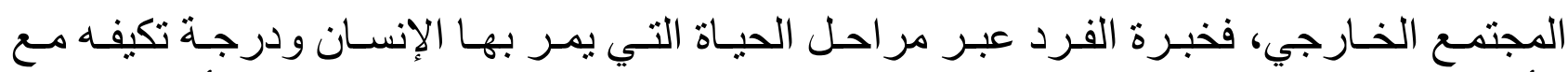

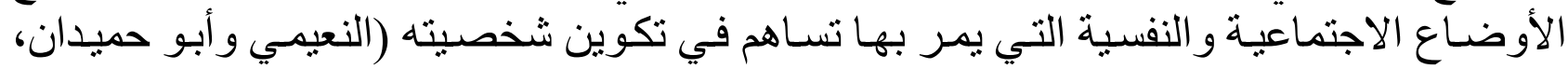

.) 2019

يعرفها الأسود (2019: 131) بأنها: هي حالة من الاستقر ار و التو افق النفسي، يعيشـها الفرد في

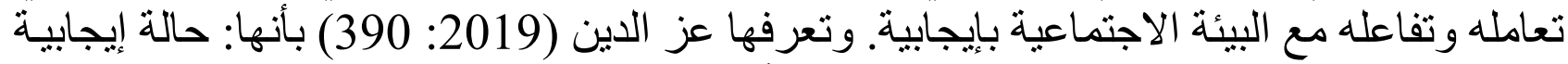

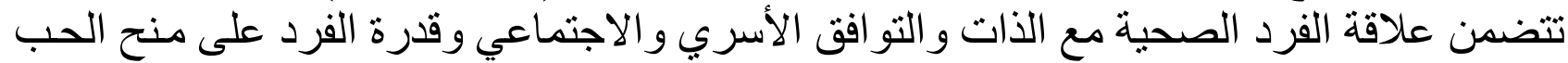

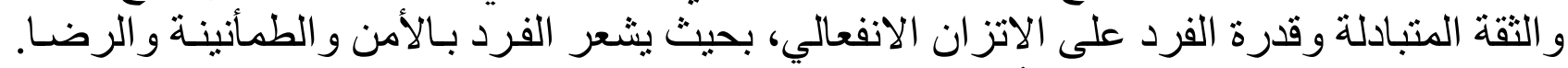

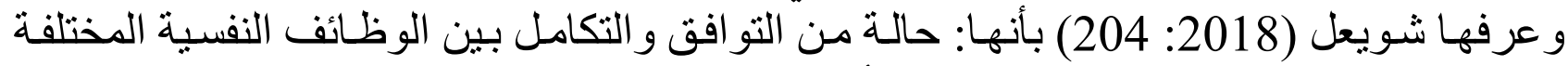

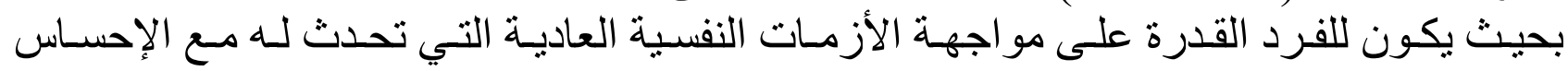
الإيجابي بالر احة و الكفاية.

وتعرفها العوض (2017: 10) بأنها: حاله إيجابيه يستطيع الفرد فيها التـاؤم مـع ذاتـه ومـع البيئة،

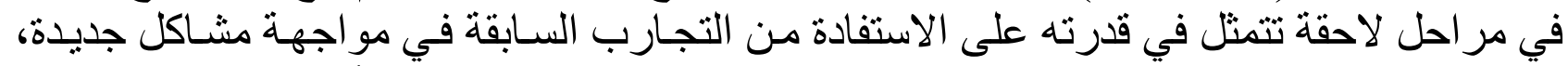

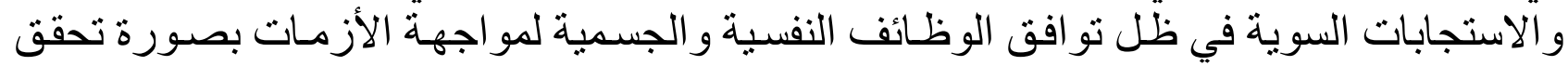

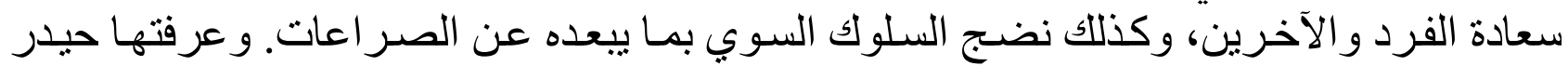

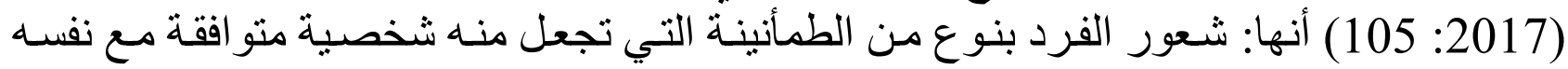

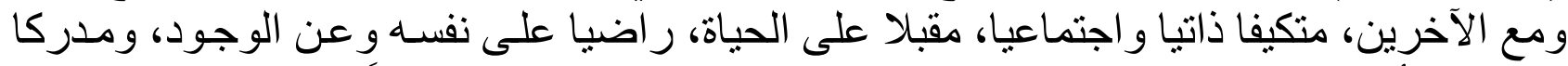

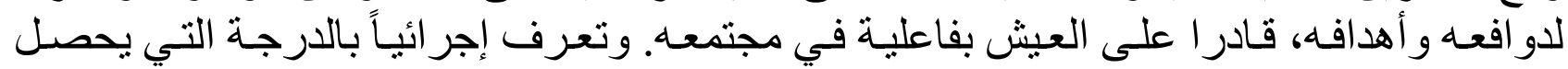

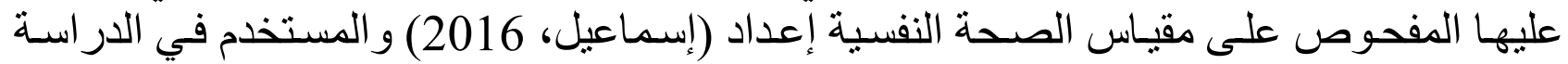
الحالية.

\section{النظريات التي تناولت الصحة النفسية:}

أولا: نظرية التحليل النفسي: يرى "فرويد" مؤسس مدرسة التحليل النفسي أن العناصـر الأساسية

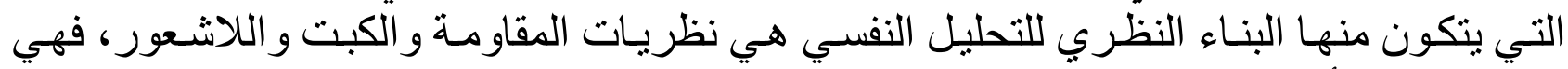

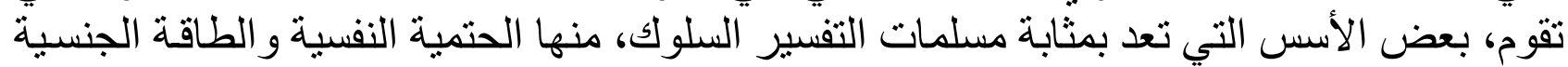

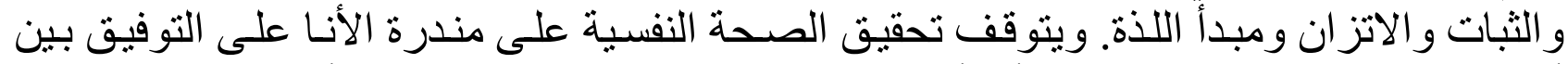

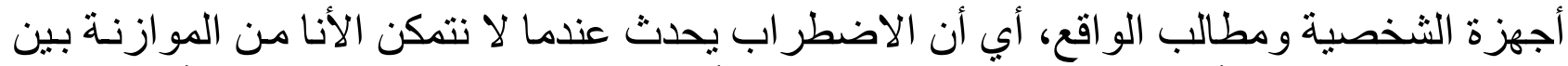

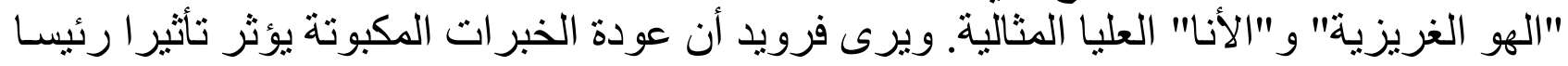

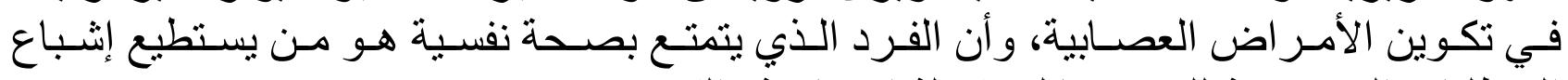
المتطلبات الضرورية للهو بوسائل مقبولة اجتماعية (القيسي، الفئ 2019).

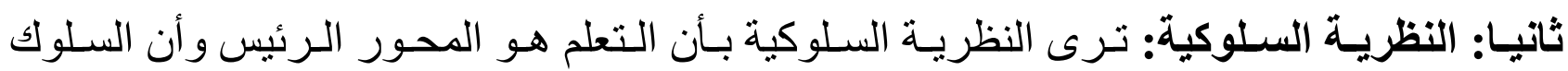

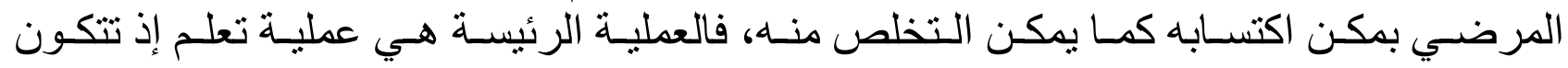

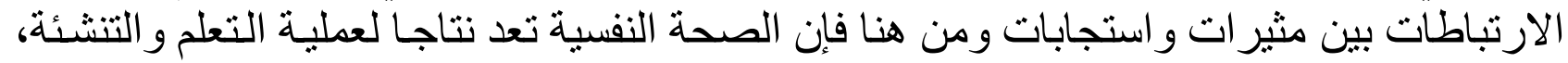

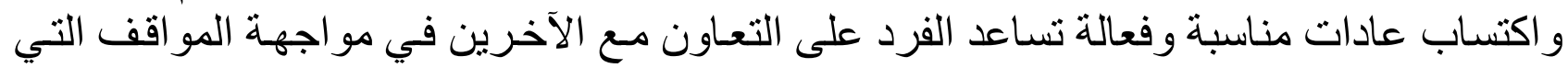

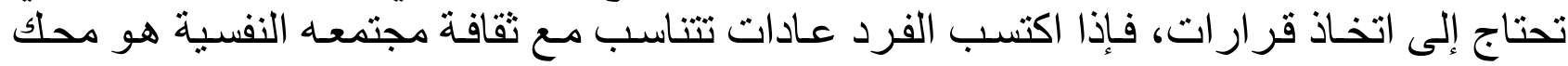

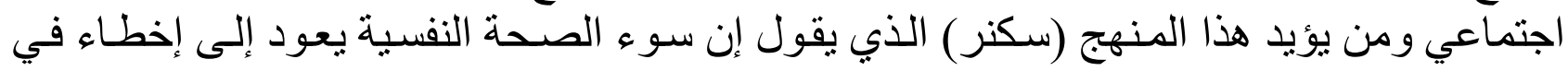




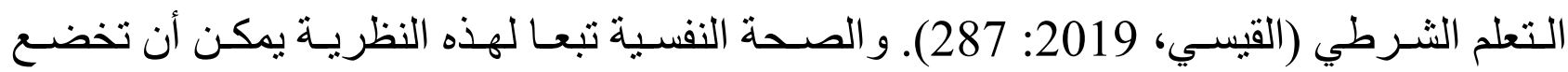

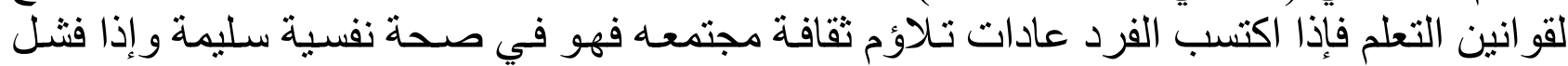

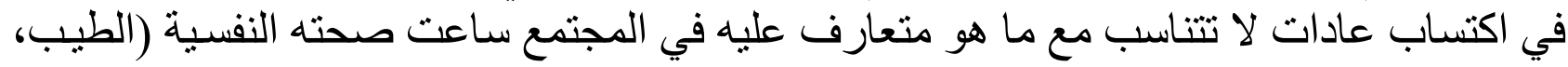

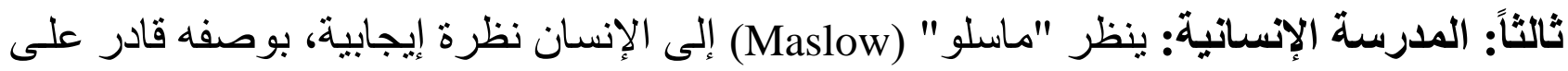

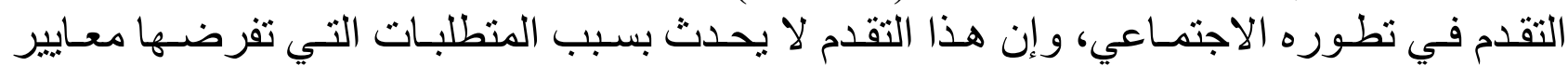

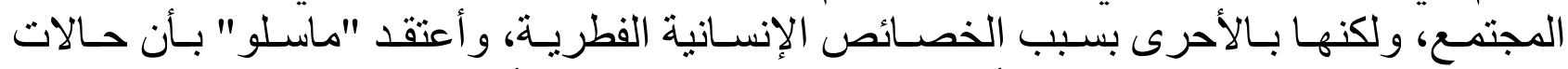

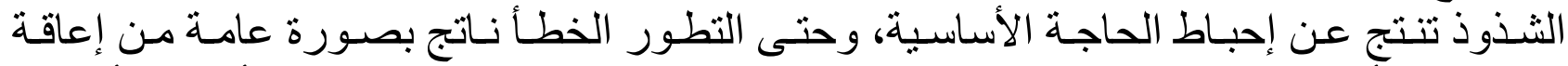

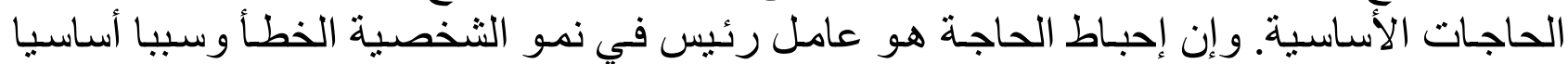

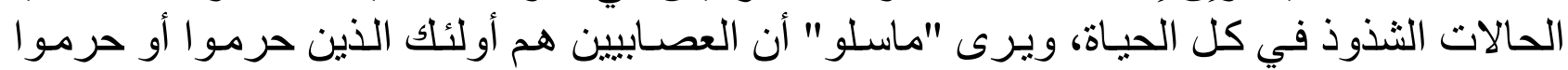

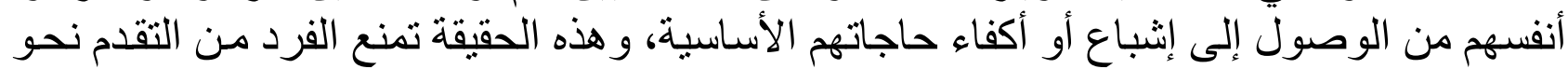

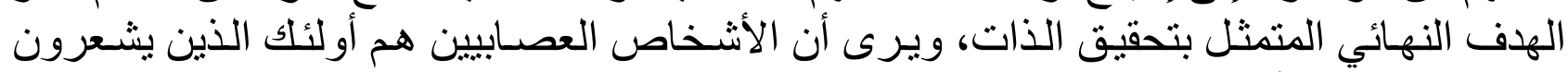
بالتهديد و انعدام الأمن و الاحتر ام القليل للذات (العبيدي، التهن الأن 2019).

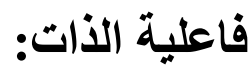

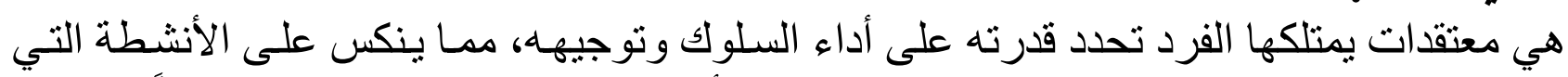

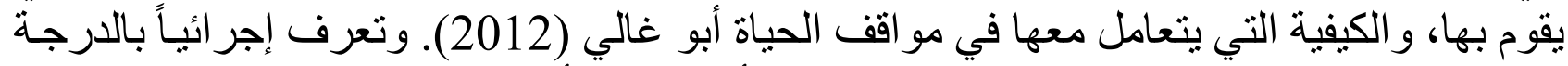

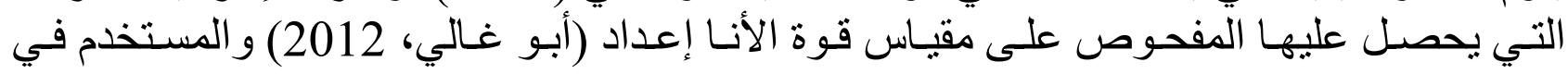
الدر اسة الحالية.

\section{نظرية التعلم الاجتماعي (باندورا):}

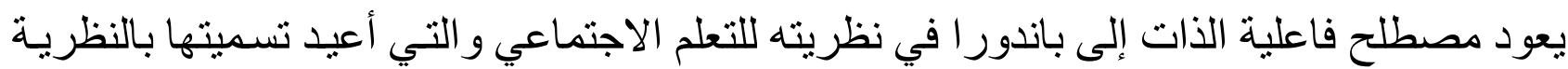

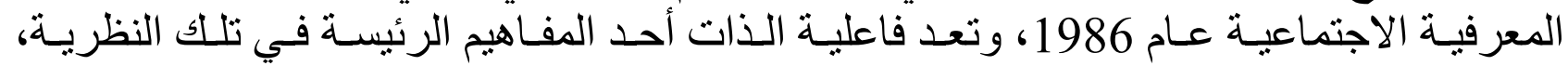

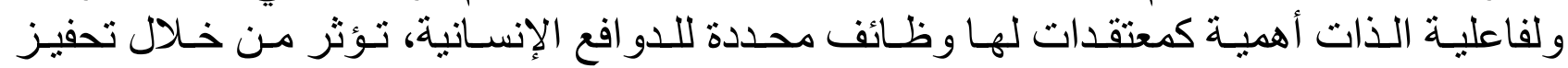

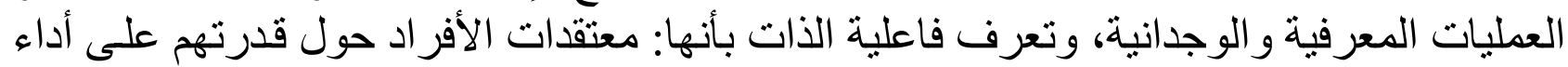

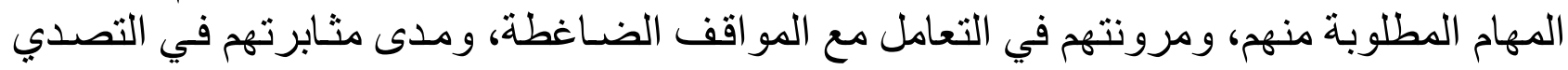
للمعوقات (Zulkosky, 2009: 94).

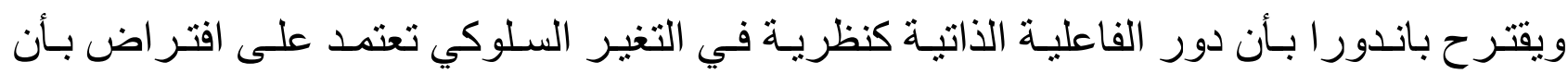

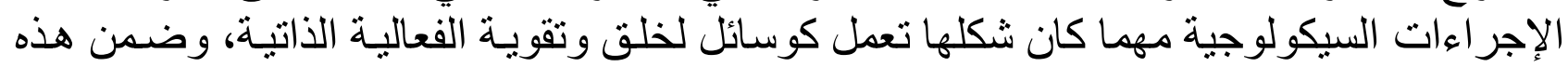

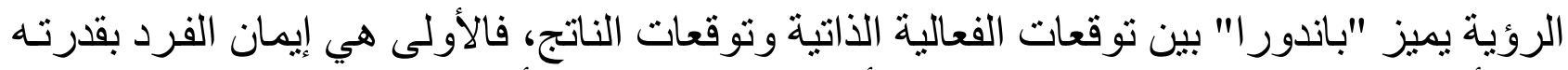

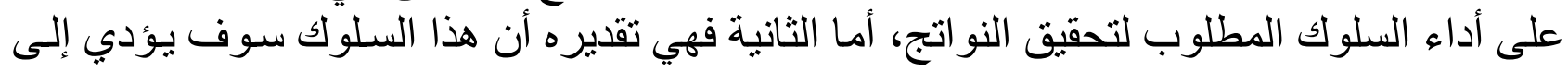

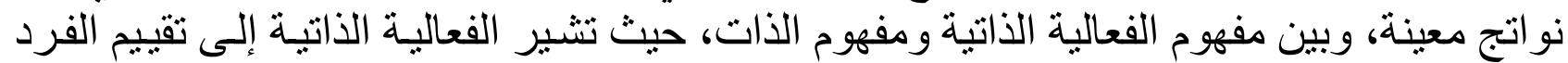

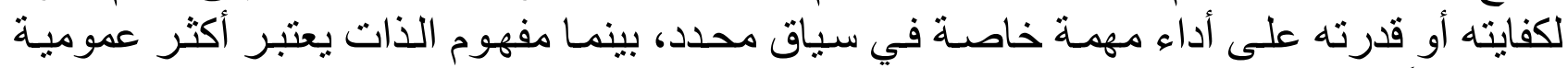

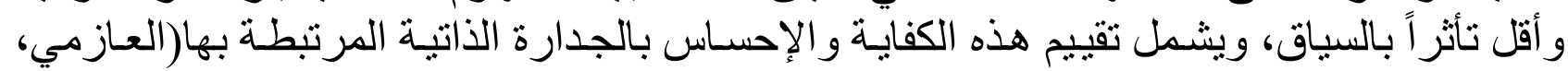
2014: 98 


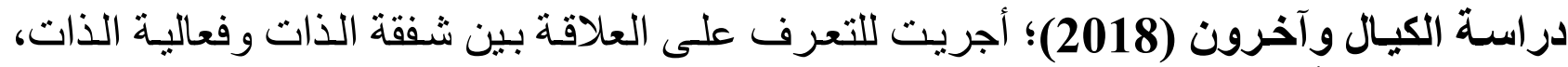

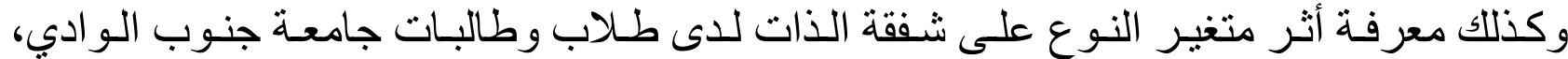

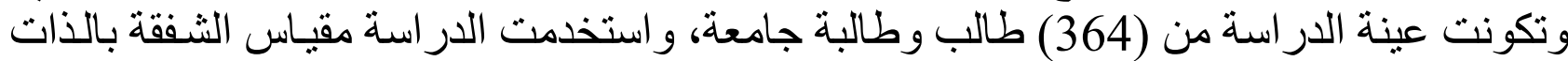

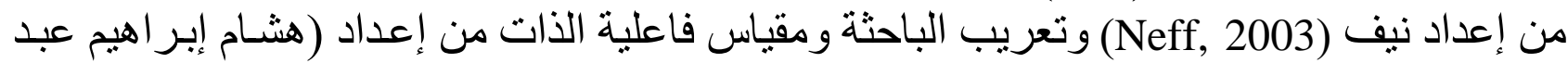

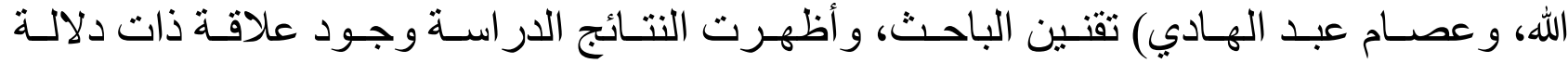

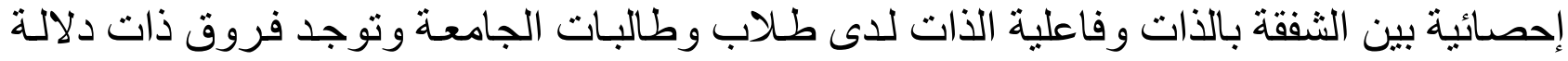
إحصائية بين متوسطات درجات الأكور.

دراسة العقاد (2016)؛ هدفت التعرف على مركز الضبط (الداخلي_الخارجي)، ومستوى إدارة

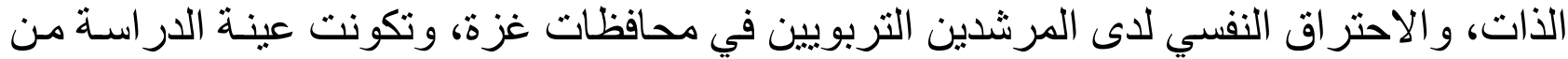

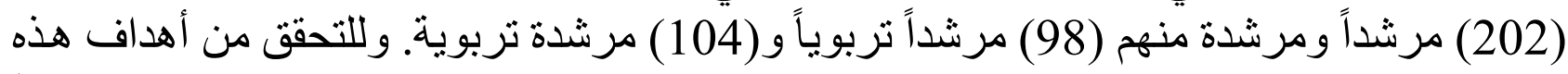

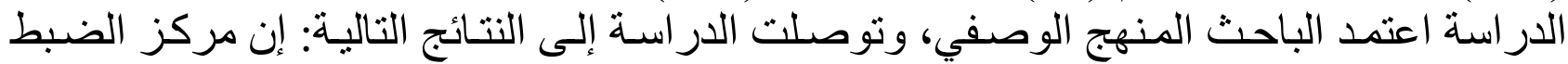

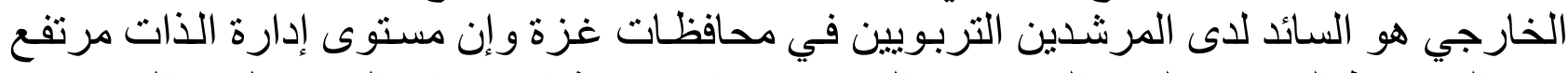

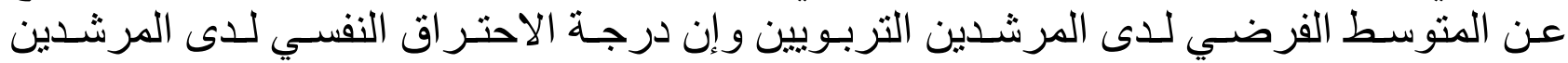
التربويين جاءت منوسطة.

\section{ثنانياً: الاراسات التي تناولت الصحة النفسية:}

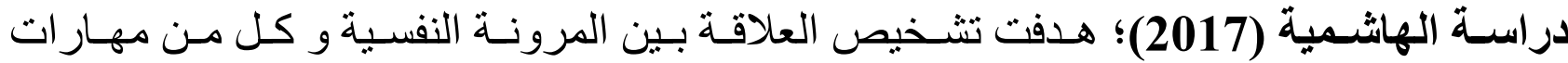

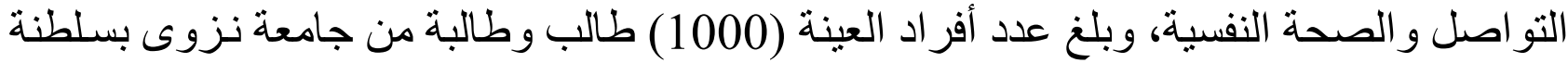

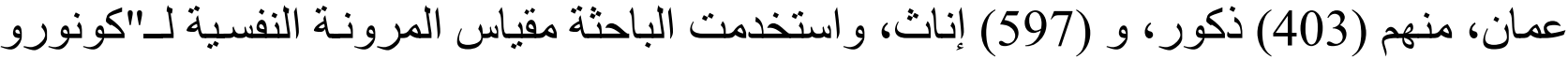

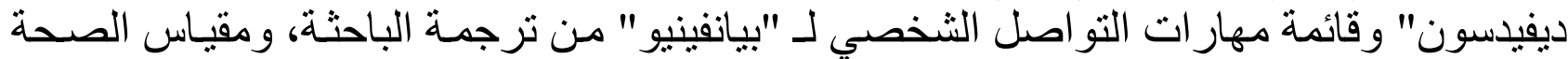

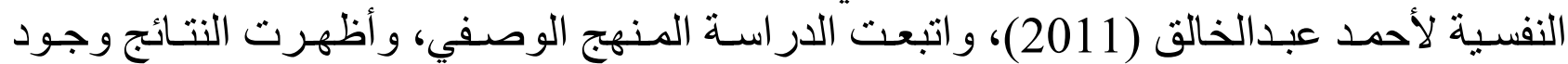

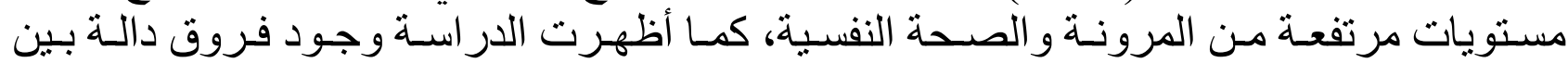

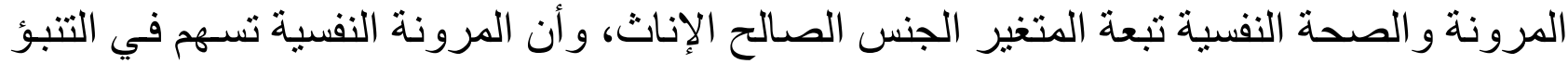

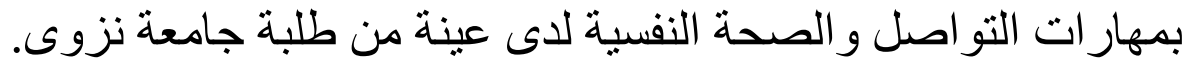

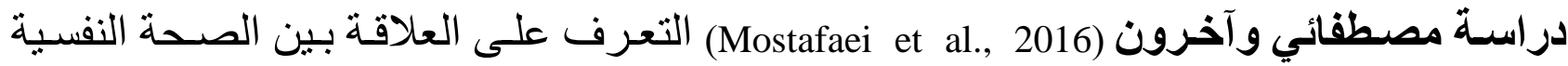

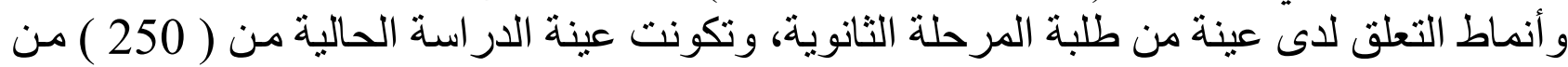

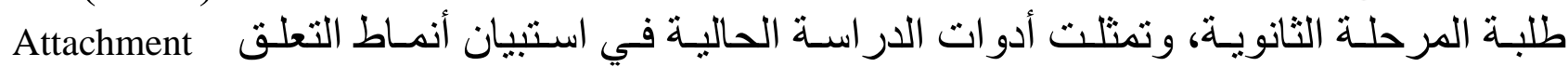

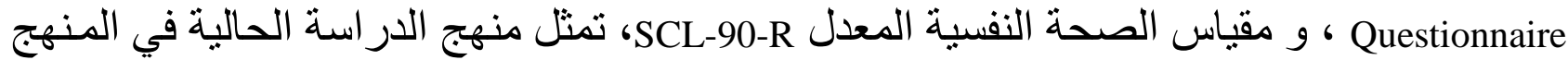

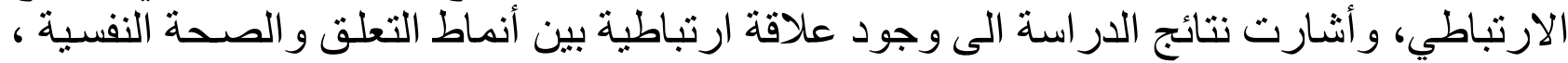

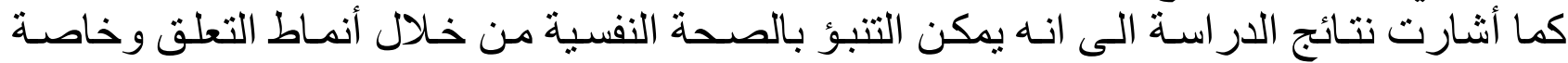

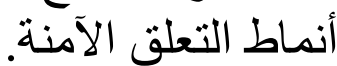

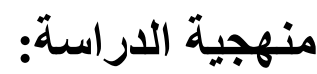
عينة الدراسة: تم اختيـار عينـة الدر اسـة بصورة عشو ائية بحيث تمثنل جزء مـن مجتمع الدر اسـة، 


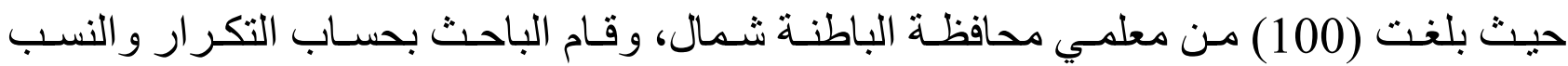

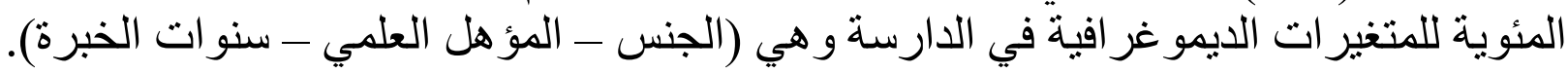

أولاً: مقياس فاعلية الذات الات

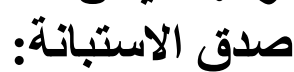

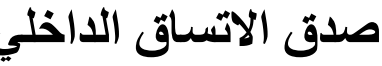

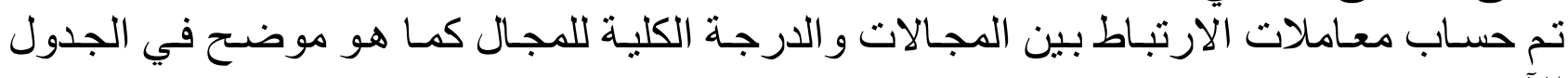
جدول (1) معاملات الارتباط بين كل مجال و الدرجة الكلية

\begin{tabular}{|c|c|c|c|}
\hline Sig & معامل الارتباط & المجال & م \\
\hline دالة عند 0.01 & $* * 0.58$ & المبادرة & 1 \\
\hline دالة عند 0.01 & $* * 0.73$ & المجهود & 2 \\
\hline دالة عند 0.01 & $* * 0.69$ & المثابرة & 3 \\
\hline
\end{tabular}

يتضح من الجدول رقم (1) أن جميع المجالات دالة إحصـائيا عند مستوى 0.01، ممـا يدل على

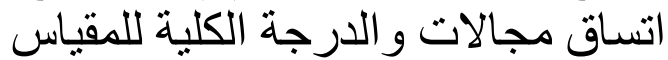

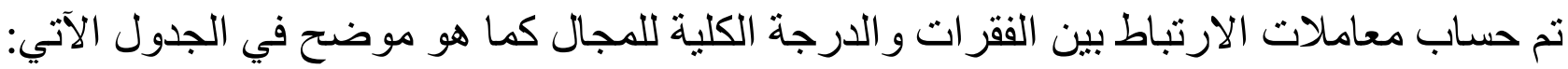

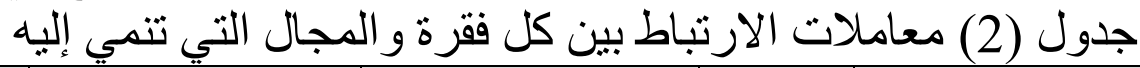

\begin{tabular}{|c|c|c|c|c|c|}
\hline معامل الارتباط & p & معامل الارتباط & r & معامل الارتباط & p \\
\hline$* * 0.85$ & 1 & $* * 0.67$ & 1 & $* * 0.88$ & 1 \\
\hline$* * 0.67$ & 2 & $* * 0.87$ & 2 & ** 0.68 & 2 \\
\hline$* * 0.75$ & 3 & $* * 0.56$ & 3 & $* * 0.85$ & 3 \\
\hline$* * 0.62$ & 4 & $* * 0.85$ & 4 & $* * 0.62$ & 4 \\
\hline$* * 0.85$ & 5 & $* * 0.78$ & 5 & $* * 0.63$ & 5 \\
\hline$* * 0.61$ & 6 & $* * 0.73$ & 6 & $* * 0.88$ & 6 \\
\hline$* * 0.67$ & 7 & $* * 0.75$ & 7 & $* * 0.84$ & 7 \\
\hline$* * 0.73$ & 8 & $* * 0.89$ & 8 & **0.68 & 8 \\
\hline$* * 0.85$ & 9 & $* * 0.58$ & 9 & ** 0.88 & 9 \\
\hline$* * 0.88$ & 10 & $* * 0.78$ & 10 & $* * 0.88$ & 10 \\
\hline
\end{tabular}

يتضح من الجدول رقم (2) أن جميع الفقرات دالة إحصائيا. الثبات من مئن

أ. معامل الثبات (طريقة ألفا كرونباوخ - Reliability Coefficients): تبين أن معامل ألفا (0.94) (0.9). جدول (3) معاملات الارتباط بين كل مجال و الدرجة الكلية

\begin{tabular}{|c|c|c|}
\hline معامل الثبات & المجال & 5 \\
\hline 0.89 & المبادرة & 1 \\
\hline 0.84 & المجهود & 2 \\
\hline 0.88 & المثابرة & 3 \\
\hline 0.94 & الارجة الكلية & \\
\hline
\end{tabular}

يتضح من الجدول رقم (3) أن جميع المجالات مرتفعة. 


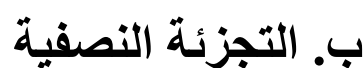

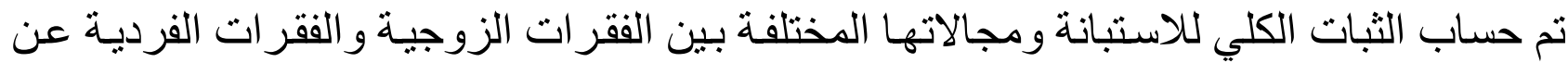

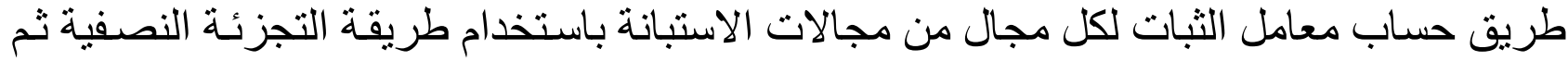

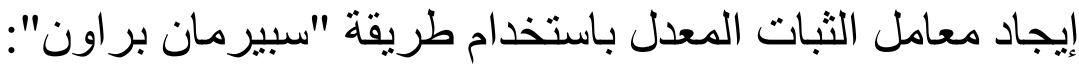

جدول (4) معاملات الارتباط لكل مجال من مجالات الاستبانة بطريقة التجزئة النصفية

\begin{tabular}{|c|c|c|}
\hline معامل الثبات مجال & معامل الثبات قبل & 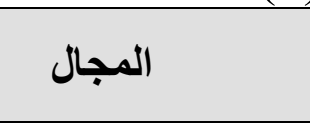 \\
\hline 0.72 & 0.66 & المبادرة \\
\hline 0.82 & 0.75 & المجهود \\
\hline 0.93 & 0.87 & المثابرة \\
\hline 0.85 & 0.78 & الدرجة الكلبة \\
\hline
\end{tabular}

يتضـح مـن الجدول رقـم (4) أن معامـل الثبـات قبـل التعديل (0.78) ومعامـل الثبـات بعد العديل

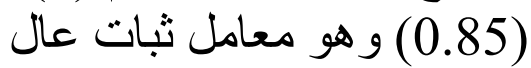

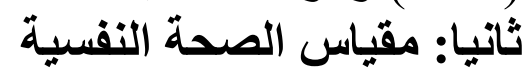

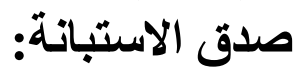
صدق الاتساق الاخلي

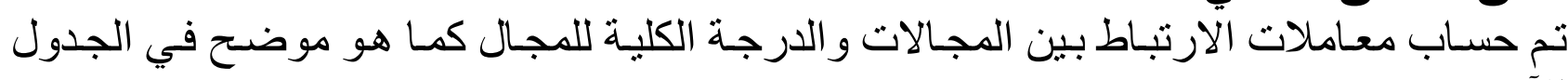
جدول (5) معاملات الارتباط بين كل مجال و الدرجة الكلية

\begin{tabular}{|c|c|c|c|}
\hline Sig & معامل الارتباط & المجال & م \\
\hline دالة عند 0.01 & $* * 0.85$ & التكيف & 1 \\
\hline دالة عند 0.01 & $* * 0.79$ & الإيجابية & 2 \\
\hline دالة عند 0.01 & $* * 0.77$ & تحقيق الذات & 3 \\
\hline دالة عند 0.01 & $* * 0.86$ & بعد الدين & 4 \\
\hline
\end{tabular}

يتضح من الجدول رقم (5) أن جميع المجالات دالة إحصـائيا عند مستوى 0.01، ممـا يدل على

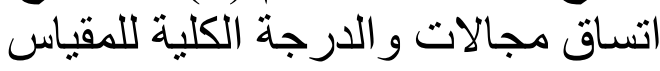

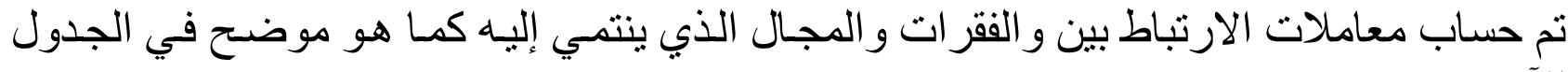
الآتي: - n

جدول (6) معاملات الارتباط بين فقرات مقياس الصحة النفسية و الدرجة الكلية للمجال

\begin{tabular}{|c|c|c|c|c|c|c|c|}
\hline الارتباط & r & الارتباط & r & معامل & b & معامل الارتباط & م \\
\hline \multicolumn{2}{|c|}{ بعد الدين } & \multicolumn{2}{|c|}{ تحقيق الذات } & \multicolumn{2}{|c|}{ الإيجابية } & \multicolumn{2}{|c|}{ التكيف } \\
\hline$* * 0.75$ & 1 & $* * 0.85$ & 1 & $* * 0.67$ & 1 & $* 0.45$ & 1 \\
\hline$* * 0.85$ & 2 & $* * 0.78$ & 2 & $* * 0.69$ & 2 & $* * 0.67$ & 2 \\
\hline$* * 0.68$ & 3 & $* * 0.78$ & 3 & $* * 0.58$ & 3 & $* * 0.78$ & 3 \\
\hline$* * 0.79$ & 4 & $* * 0.86$ & 4 & $* * 0.79$ & 4 & $* 0.45$ & 4 \\
\hline
\end{tabular}




\begin{tabular}{|c|c|c|c|c|c|c|c|}
\hline$* * 0.69$ & 5 & $* * 0.88$ & 5 & $* * 0.85$ & 5 & $* * 0.78$ & 5 \\
\hline$* * 0.85$ & 6 & & & $* * 0.77$ & 6 & $* * 0.62$ & 6 \\
\hline$* * 0.78$ & 7 & & & $* * 0.61$ & 7 & & \\
\hline$* * 0.69$ & 8 & & & $* * 0.72$ & 8 & & \\
\hline$* * 0.88$ & 9 & & & $* * 0.69$ & 9 & & \\
\hline$* * 0.78$ & 10 & & & $* * 0.78$ & 10 & & \\
\hline$* * 0.69$ & 11 & & & & & & \\
\hline$* * 0.85$ & 12 & & & & & & \\
\hline$* * 0.78$ & 13 & & & & & & \\
\hline$* * 0.84$ & 14 & & & & & & \\
\hline$* * 0.88$ & 15 & & & & & & \\
\hline
\end{tabular}

|// غير دالة إحصائيا

* دالة عند مستوى 0.05

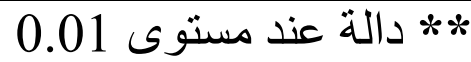
يتضح من الجدول (6) أن جميع فقر ات دالة إحصائيا

الثبات: قام الباحث بايجاد معامل الثبات :

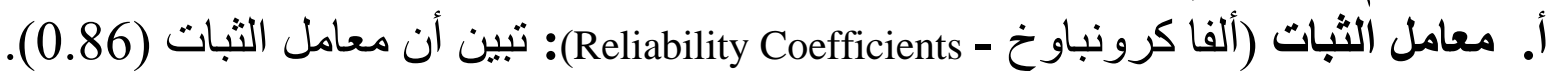
جدول (7) معاملات الارتباط بين كل مجال و الدرجة الكلية

\begin{tabular}{|c|c|c|}
\hline معامل الثبات & المجال & م \\
\hline 0.78 & التكيف & 1 \\
\hline 0.85 & الإيجابية & 2 \\
\hline 0.88 & تحقيق الذات & 3 \\
\hline 0.88 & بعد الدين & 4 \\
\hline 0.86 & الدرجة الكلية & \\
\hline
\end{tabular}

يتضح من الجدول رقم (7) أن جميع المجالات دالة إحصائيا عند مستوى 0.01

ب. التجزئة النصفية

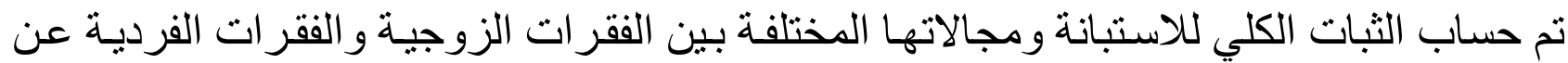

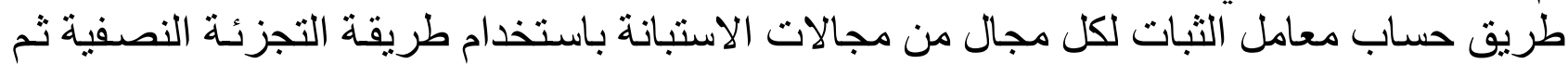

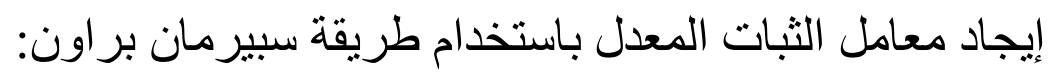

جدول (8) معاملات الارتباط لكل مجال من مجالات الاستبانة بطريقة التجزئة النصفية

\begin{tabular}{|c|c|c|}
\hline معامل الثبات مجال & معامل الثبات قبل & المجال \\
\hline 0.924 & 0.858 & التكيف \\
\hline 0.959 & 0.922 & الإيجابية \\
\hline 0.965 & 0.933 & تحقيق الذات \\
\hline 0.946 & 0.898 & بعد الدين \\
\hline 0.945 & 0.895 & الدرجة الكلية \\
\hline
\end{tabular}

يتضـح من الجدول رقم (845) أن معامل الثبـات قبل التعديل (0.895) ومعامل الثبـات بعد العديل (0.945) وهو معامل ثبات عال 


\section{الأساليب الإحصائية:}

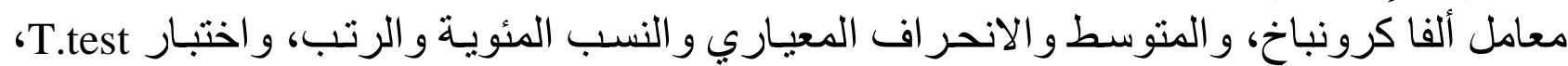
التبيان الأحادي الفيرون

تحليل النتائج وتفسير ها: استخدم الباحث الوسط الحسئي ولفي والانحر اف المعياري والنسب المئوية والرتب للإجابة عن أسئلة

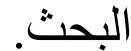

للإجابة عن السؤال الأول الأي ينص على: ما مستوى فاعلية الذات لاى المعلمين؟

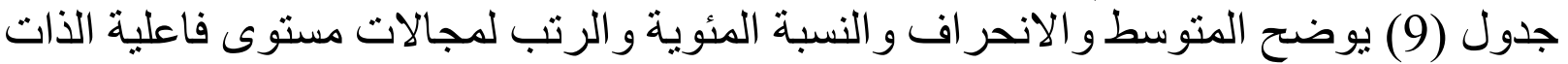

\begin{tabular}{|c|c|c|c|c|c|}
\hline الرتبة & المئوية & المعياري & الحستوسي & البعد & p \\
\hline 2 & 58.76 & 0.76 & 2.94 & المبادرة & 1 \\
\hline 3 & 56.86 & 0.75 & 2.84 & المجهود & 2 \\
\hline 1 & 66.28 & 0.41 & 3.31 & المثابرة & 3 \\
\hline & 0.51 & 3.03 & البعد الكلي & \\
\hline
\end{tabular}

أشارت نتائج الدر اسة أن نسبة مستوى فاعلية الذات لدى المعلمين بلغت (60.63\%) وهو مستوى

\section{أشارت نتائج تحليل الجدول أعلاه إلى:}

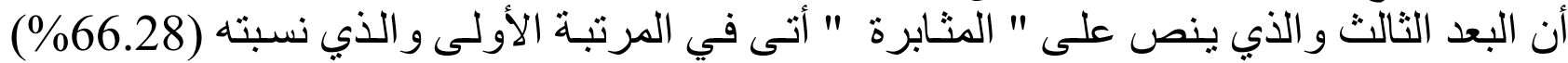

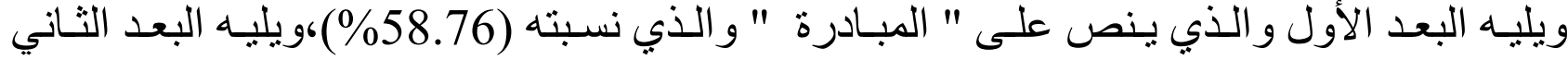

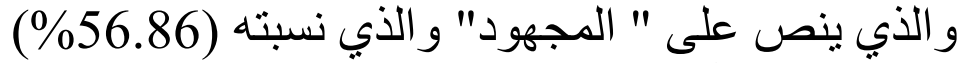

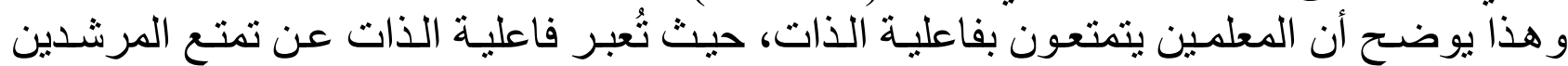

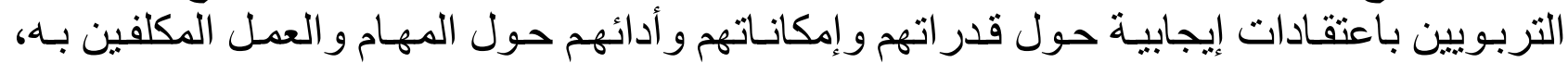

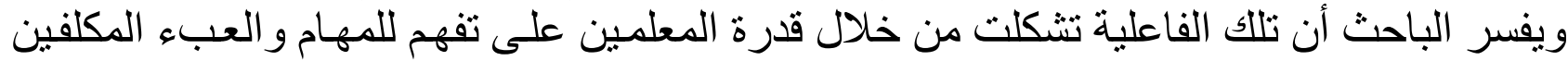

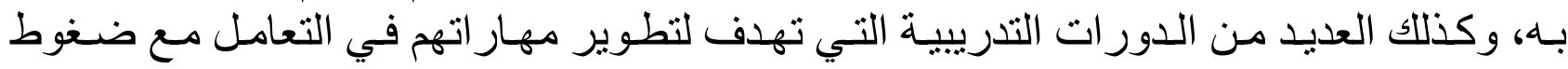
العمل، وكذللك تطوير مهار اتهر.

للإجابة على السؤال الثاني والذي ينص على: ما مستوى الصحة النفسية لدى المعمين؟ جدول (10) يوضح المتوسط و الانحر اف و النسبة المئوية و الرتب لمجالات مستوى الصحة النفسية

\begin{tabular}{|c|c|c|c|c|c|}
\hline الرتبة & المئويبة & المعياري & الحسابي & البعد & م \\
\hline 2 & 67.43 & 0.44 & 3.37 & التكيف & 1 \\
\hline 3 & 62.36 & 0.46 & 3.12 & الإيجابية & 2 \\
\hline 1 & 69.64 & 0.45 & 3.48 & تحقيق الذات & 3 \\
\hline 4 & 57.08 & 0.37 & 2.85 & بعد الدين & 4 \\
\hline \multicolumn{2}{|c|}{62.02} & 0.3 & 3.1 & \multicolumn{2}{|l|}{ البعد الكلي } \\
\hline
\end{tabular}

أثنارت النتائج أن نسبة مستوى الصحة النفسية لدى المعلمين بلغت مستوى منوسط (62.02\%). 


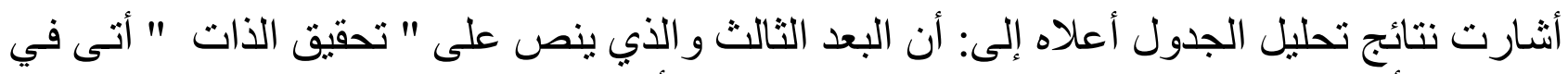

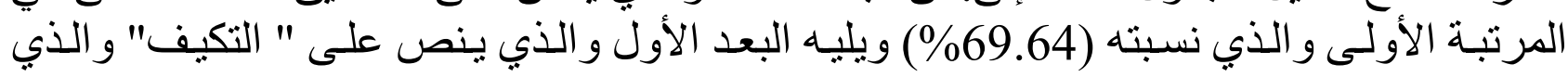

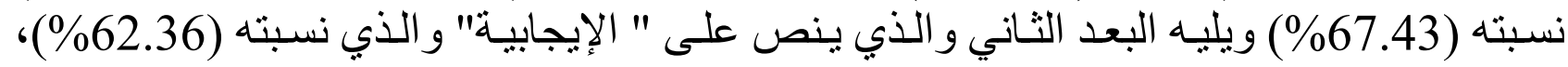
ويليه البعد الر ابع والذي ينص على "بعد البعد الدين" والذي نسبته (57.08\%).

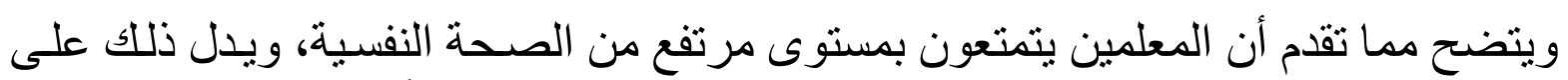

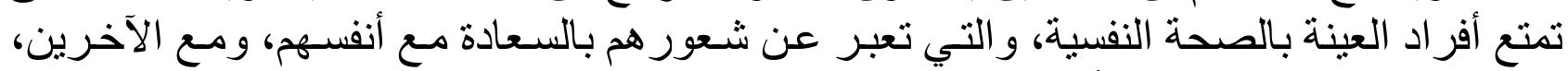
وكذلك التكيف مع مجريات و أحداث الحينة بالهياة.

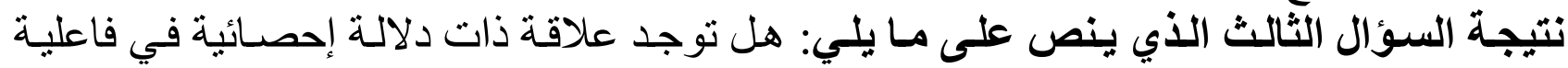

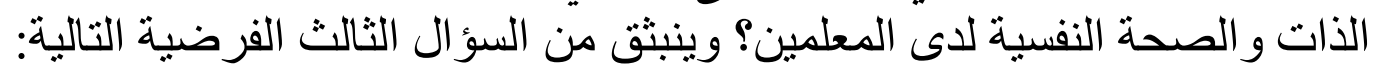

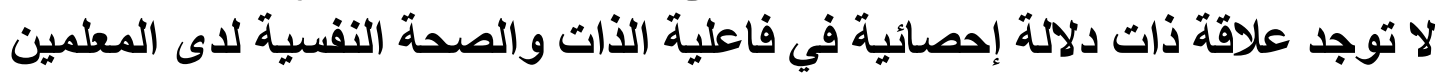

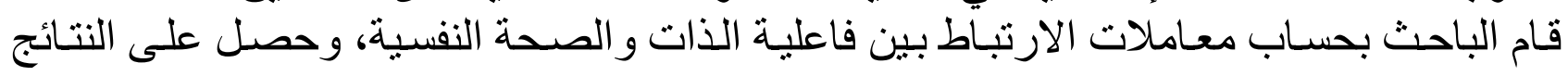
التالية:

جدول (11)معاملات الارتباط بيرسون بين فاعلية الذات و الصحة النفسية

\begin{tabular}{|c|c|c|c|c|c|}
\hline النفسية & بعد الدين & تحقيق & الإيجابية & التكيف & المقياس \\
\hline$* * 0.71$ & $* * 0.56$ & $* * 0.49$ & $* * 0.72$ & $* * 0.88$ & المبادرة \\
\hline$* * 0.56$ & $* * 0.47$ & $* * 0.56$ & $* * 0.56$ & $* * 0.66$ & 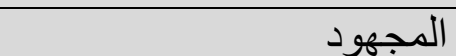 \\
\hline$* * 0.76$ & $* * 0.56$ & $* * 0.65$ & $* * 0.67$ & $* * 0.56$ & المثابرة \\
\hline$* * 0.68$ & $* * 0.55$ & $* * 0.68$ & $* * 0.48$ & $* * 0.61$ & الدرجة الكلية (فاعلية الذات) \\
\hline
\end{tabular}

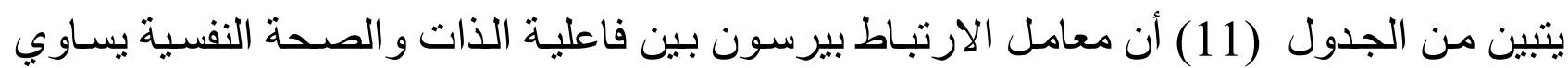

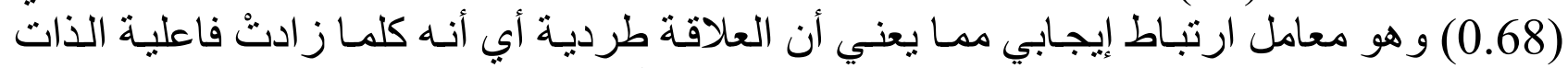

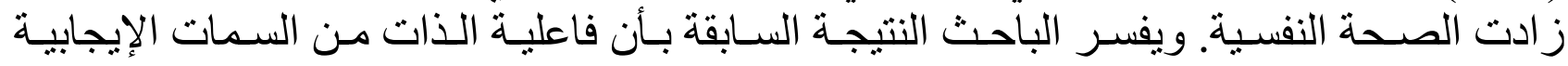

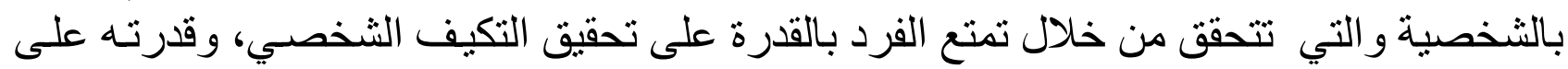

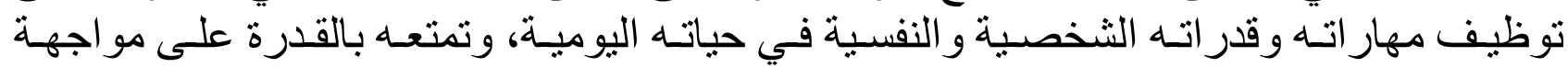

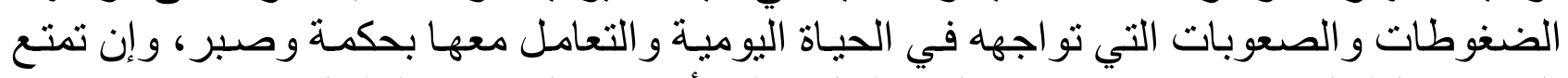

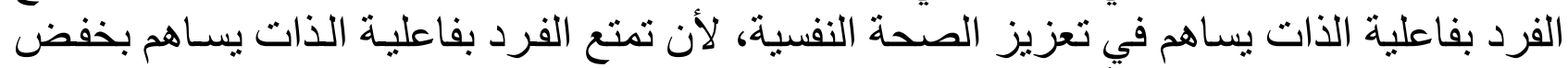

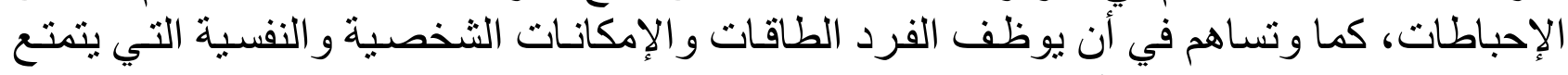

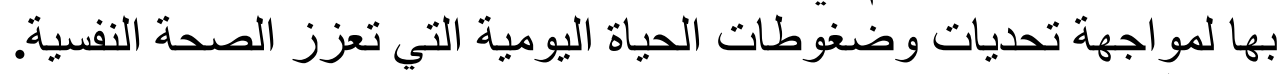

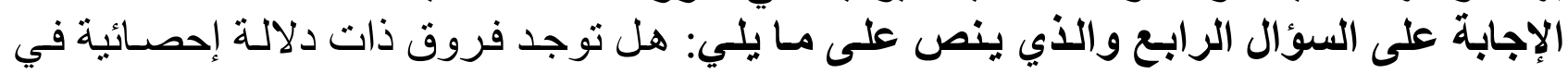

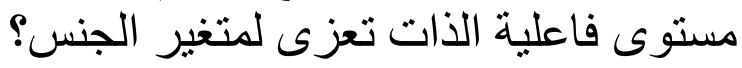
وينبتق من السؤال الر ابع الفرضية التئية التالية:

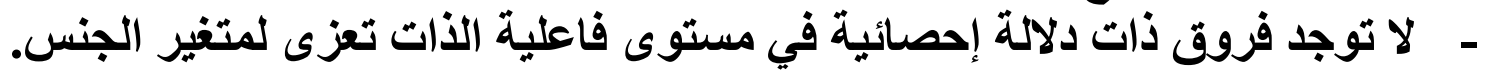

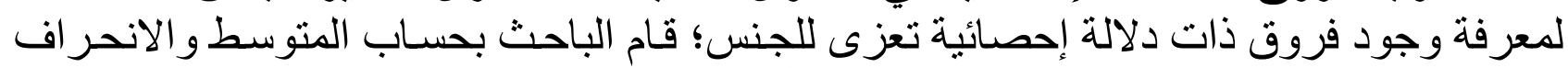

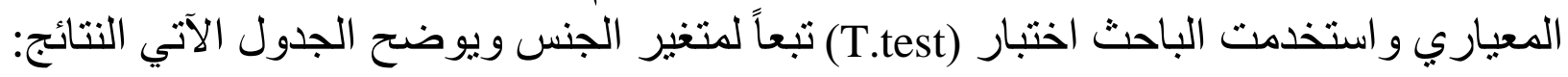
جدول رقم (12) المتوسط والقيمة المحوسبة ودلالتها تعزى الجنس 
IJASOS- International E-Journal of Advances in Social Sciences, Vol. VI, Issue 16, April 2020

\begin{tabular}{|c|c|c|c|c|c|c|}
\hline الدسلالة & قيمة "ت & الالانحرياري & المتوسط & التكر ار & الجنس & البعد \\
\hline \multirow{2}{*}{0.77} & \multirow{2}{*}{0.283} & 0.782 & 2.92 & 64 & ذكر & \multirow{2}{*}{ المبادرة } \\
\hline & & 0.718 & 2.97 & 36 & أنثىى & \\
\hline \multirow{2}{*}{0.87} & \multirow{2}{*}{0.152} & 0.769 & 2.85 & 64 & ذكر & \multirow{2}{*}{ المجهود } \\
\hline & & 0.713 & 2.83 & 36 & أننثى & \\
\hline \multirow{2}{*}{0.86} & \multirow{2}{*}{0.154} & 0.378 & 3.32 & 64 & ذكر & \multirow{2}{*}{ المثابرة } \\
\hline & & 0.467 & 3.31 & 36 & أنثىى & \\
\hline \multirow{2}{*}{0.98} & \multirow{2}{*}{0.02} & 0.552 & 3.03 & 64 & ذكر & \multirow{2}{*}{ الدرجة الكلية } \\
\hline & & 0.444 & 3.03 & 36 & أنثى & \\
\hline
\end{tabular}

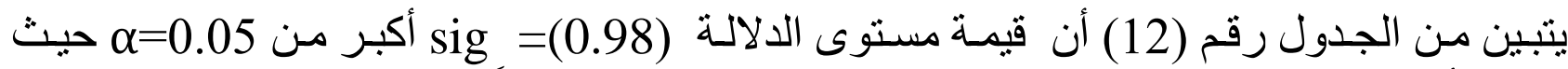

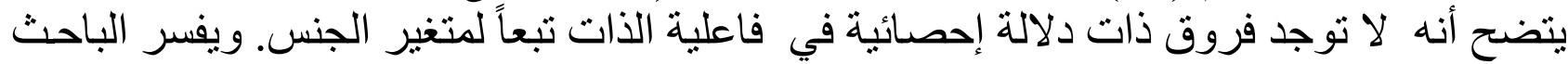

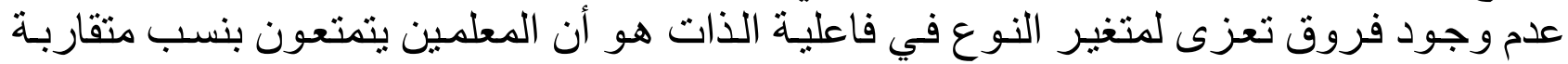

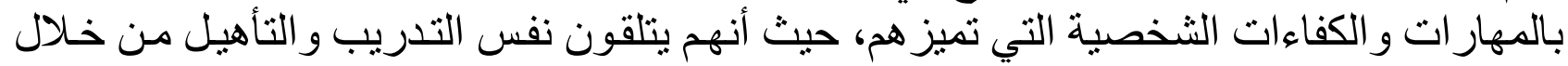

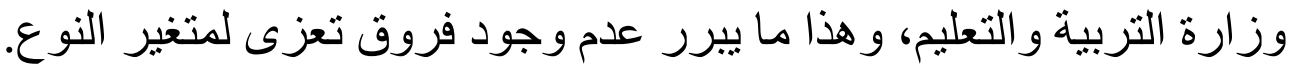

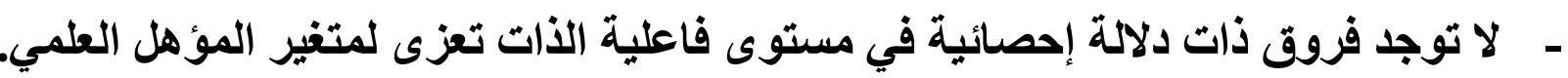

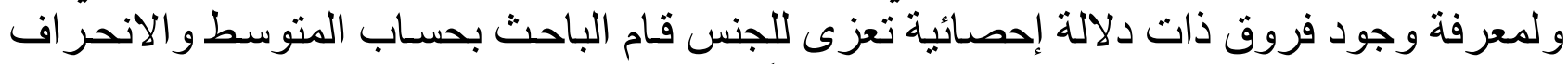

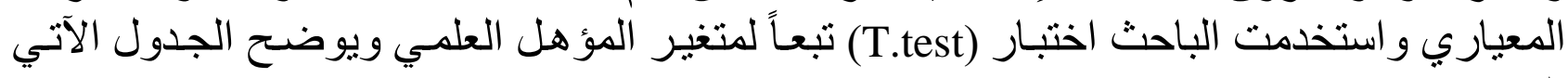

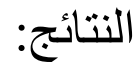

\begin{tabular}{|c|c|c|c|c|c|c|}
\hline مستوى الدلاكة & قيمة "ت & الالمعرافي & المتوسط & التكرار & العؤهي & البعد \\
\hline \multirow[b]{2}{*}{0.47} & \multirow[b]{2}{*}{0.71} & 0.78 & 2.97 & 80 & بكالوريوس & \multirow[b]{2}{*}{ المبادرة } \\
\hline & & 0.662 & 2.83 & 20 & دراسات & \\
\hline \multirow[b]{2}{*}{0.35} & \multirow[b]{2}{*}{0.92} & 0.786 & 2.88 & 80 & بكالوريوس & \multirow[b]{2}{*}{ المجهود } \\
\hline & & 0.553 & 2.71 & 20 & دراسات & \\
\hline \multirow[b]{2}{*}{0.47} & \multirow[b]{2}{*}{0.77} & 0.418 & 3.33 & 80 & بكالوريوس & \multirow[b]{2}{*}{ المثابرة } \\
\hline & & 0.38 & 3.26 & 20 & 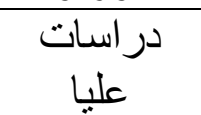 & \\
\hline \multirow[b]{2}{*}{0.32} & \multirow[b]{2}{*}{0.98} & 0.528 & 3.06 & 80 & بكالوريوس & \multirow[b]{2}{*}{ الدرجة الكلية } \\
\hline & & 0.45 & 2.93 & 20 & دراسات & \\
\hline
\end{tabular}

يتبين من الجدول رقم (13) أن قيمة مستوى الدلالة (0.32)=

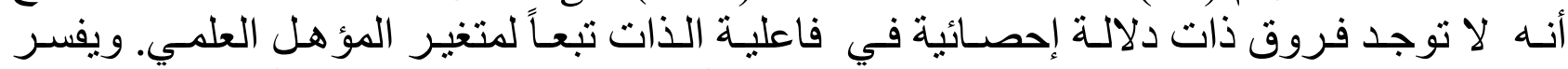

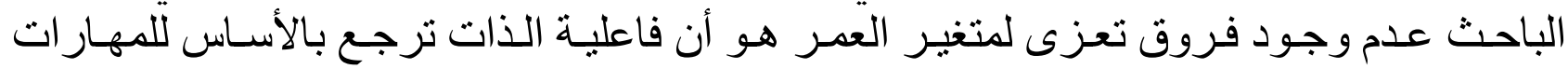




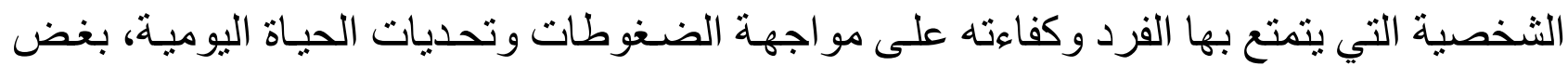

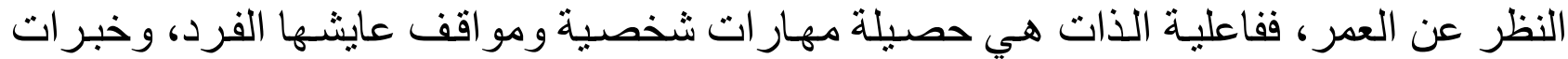

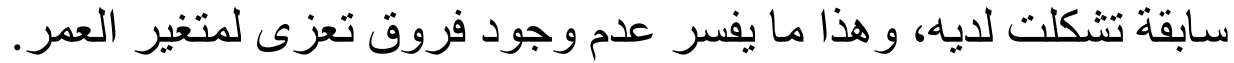

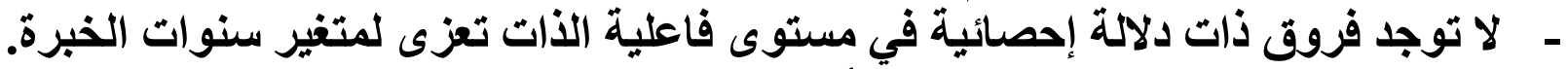

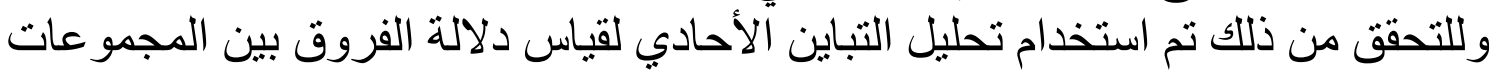

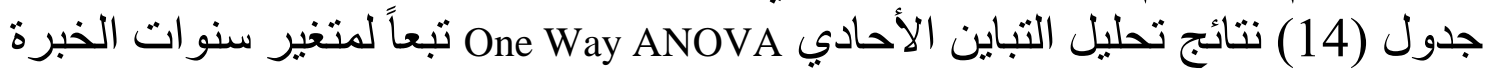

\begin{tabular}{|c|c|c|c|c|c|c|}
\hline مستوي & قيمة & المربعات & الدرجية & المربعوع & مصدر التباين & المجالات \\
\hline \multirow{3}{*}{0.7} & \multirow{3}{*}{0.41} & 0.234 & 2 & 0.47 & بين المجمو عات & \multirow{3}{*}{ المبادرة } \\
\hline & & 0.579 & 97 & 56.2 & داخل المجمو عات & \\
\hline & & & 99 & 56.6 & المجموع & \\
\hline \multirow{3}{*}{0.7} & \multirow{3}{*}{0.36} & 0.201 & 2 & 0.4 & بين المجموعات & \multirow{3}{*}{ المجهود } \\
\hline & & 0.563 & 97 & 54.6 & داخل المجمو عات & \\
\hline & & & 99 & 55 & المجموع & \\
\hline \multirow{3}{*}{0.1} & \multirow{3}{*}{2.31} & 0.379 & 2 & 0.76 & بين المجموعات & \multirow{3}{*}{ المثابرة } \\
\hline & & 0.164 & 97 & 15.9 & داخل المجمو عات & \\
\hline & & & 99 & 16.7 & المجموع & \\
\hline \multirow{3}{*}{0.8} & \multirow{3}{*}{0.25} & 0.066 & 2 & 0.13 & بين المجموعات & \multirow{3}{*}{ الكلية } \\
\hline & & 0260 & 97 & 26 & داخل المجمو عات & \\
\hline & & 0.268 & 99 & 26.1 & المجموع & \\
\hline
\end{tabular}

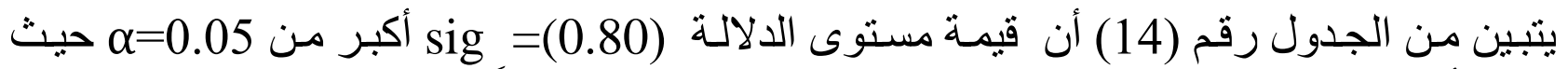

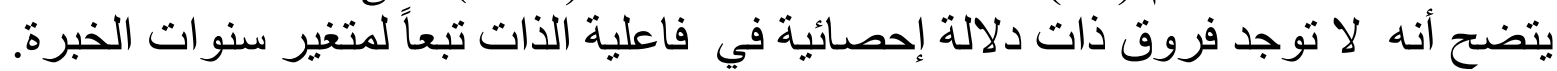

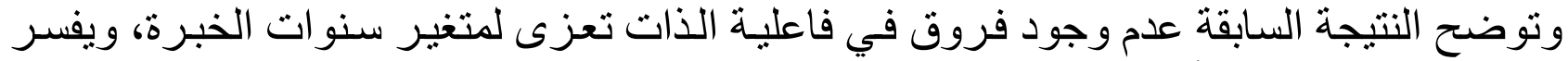

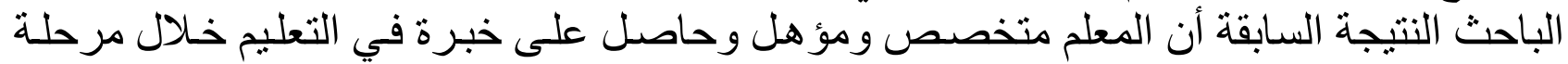

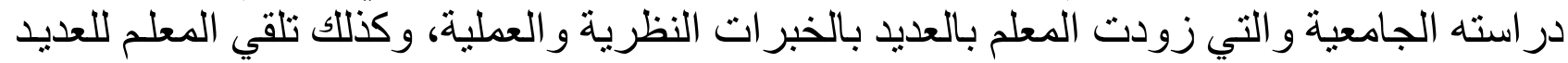

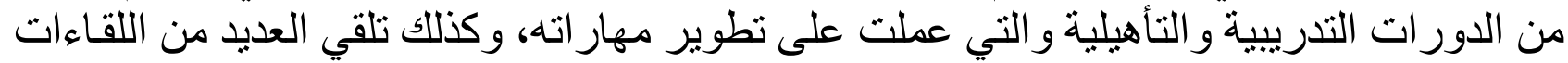

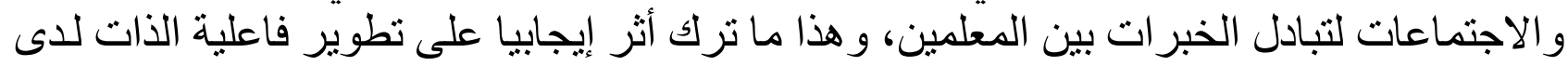

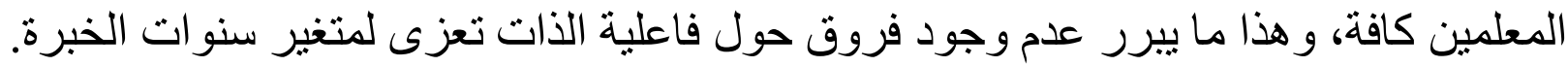

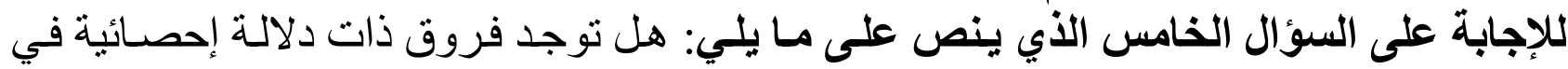

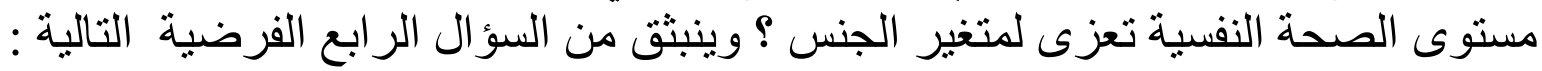

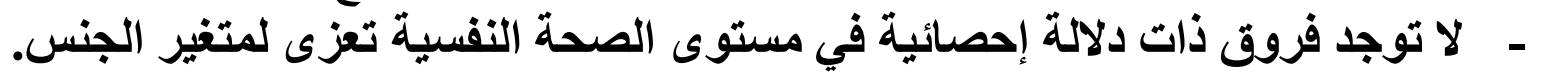

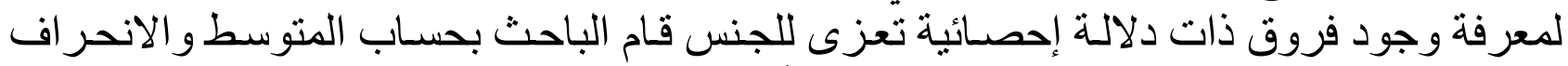

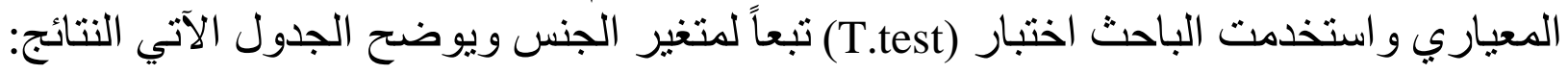

\begin{tabular}{|c|c|c|c|c|c|c|}
\hline مستوي & قيمة "ت لـ لـ & 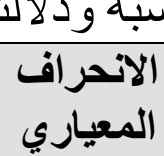 & المتوسط الدح & التكرار & الجنس & البعد \\
\hline 0.57 & 0.56 & 0.41 & 3.39 & 64 & ذكر & التكيف \\
\hline
\end{tabular}


IJASOS- International E-Journal of Advances in Social Sciences, Vol. VI, Issue 16, April 2020

\begin{tabular}{|c|c|c|c|c|c|c|}
\hline & & 0.506 & 3.34 & 36 & أنثى & \\
\hline \multirow{2}{*}{0.31} & \multirow{2}{*}{1.04} & 0.377 & 3.15 & 64 & ذكر & \multirow[t]{2}{*}{ الإيجابية } \\
\hline & & 0.577 & 3.06 & 36 & أنتى & \\
\hline \multirow{2}{*}{0.72} & \multirow{2}{*}{0.34} & 0.431 & 3.49 & 64 & ذكر & \multirow[t]{2}{*}{ تحقيق الذات } \\
\hline & & 0.485 & 3.46 & 36 & أنتى & \\
\hline \multirow{2}{*}{0.97} & \multirow{2}{*}{0.03} & 0.363 & 2.85 & 64 & ذكر & \multirow{2}{*}{ الدرجة الكلية } \\
\hline & & 0.393 & 2.86 & 36 & أنثى & \\
\hline \multirow{2}{*}{0.53} & \multirow{2}{*}{0.62} & 0.253 & 3.12 & 64 & ذكر & \multirow{2}{*}{ الدرجة الكلية } \\
\hline & & 0.381 & 3.08 & 36 & أنثى & \\
\hline
\end{tabular}

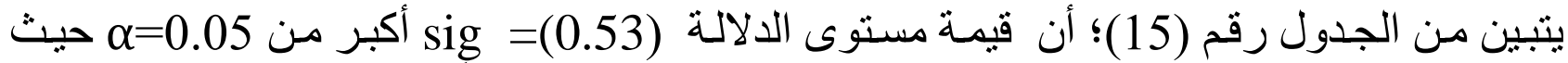

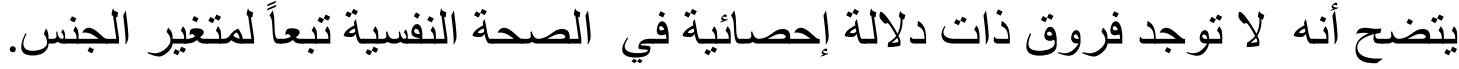

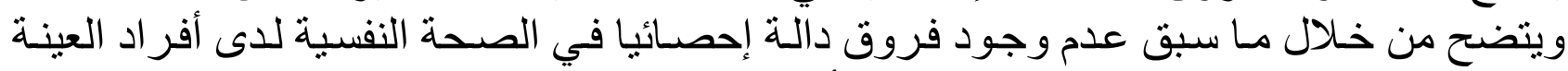

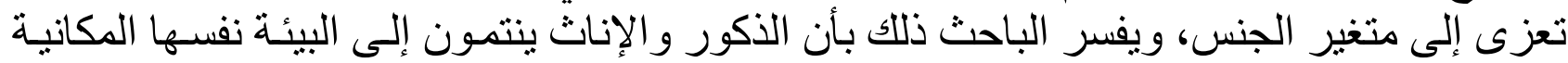

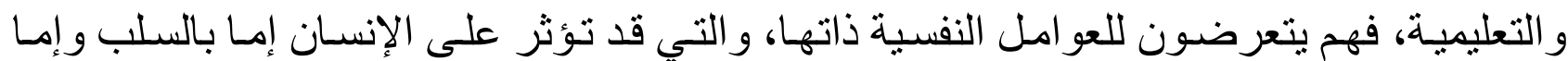

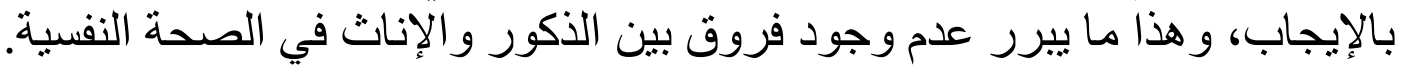

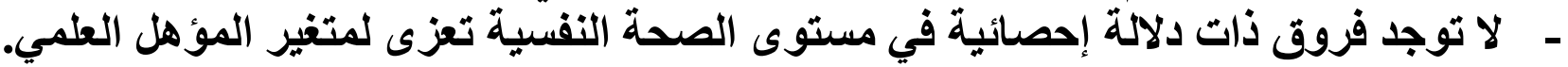

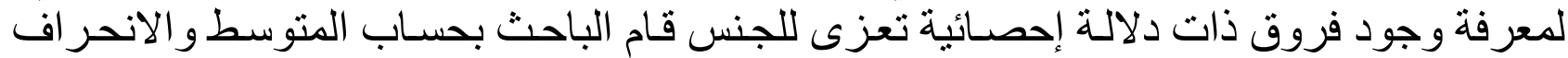

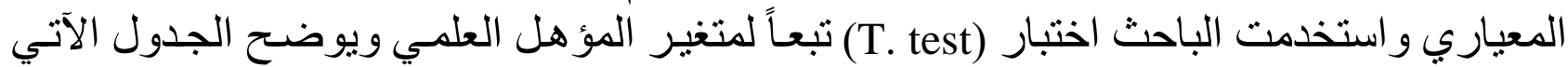

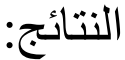

\begin{tabular}{|c|c|c|c|c|c|c|}
\hline مستوى الدلالة & "تيمة " قات " & الانحر اف & المتوسط & التكر ار & العؤهل & البعد \\
\hline \multirow[b]{2}{*}{0.97} & \multirow[b]{2}{*}{0.43} & 0.461 & 3.37 & 80 & بكالوريوس & \multirow[t]{2}{*}{ التكيف } \\
\hline & & 0.386 & 3.38 & 20 & دراسات & \\
\hline \multirow[b]{2}{*}{0.50} & \multirow[b]{2}{*}{0.34} & 0.47 & 3.1 & 80 & بكالوريوس & \multirow[t]{2}{*}{ الإيجابية } \\
\hline & & 0.418 & 3.18 & 20 & در اسات & \\
\hline \multirow[b]{2}{*}{0.89} & \multirow[b]{2}{*}{0.13} & 0.46 & 3.49 & 80 & بكالوريوس & \multirow[t]{2}{*}{ تحقيق الذات } \\
\hline & & 0.412 & 3.47 & 20 & در اسات & \\
\hline \multirow[b]{2}{*}{0.76} & \multirow[b]{2}{*}{0.30} & 0.392 & 2.85 & 80 & بكالوريوس & \multirow[b]{2}{*}{ الدرجة الكلية } \\
\hline & & 0.288 & 2.88 & 20 & در اسات & \\
\hline \multirow{2}{*}{0.67} & \multirow{2}{*}{0.47} & 0.317 & 3.09 & 80 & بكالوريوس & \multirow{2}{*}{ الدرجة الكلية } \\
\hline & & 0.252 & 3.13 & 20 & در اسات & \\
\hline
\end{tabular}


عليا

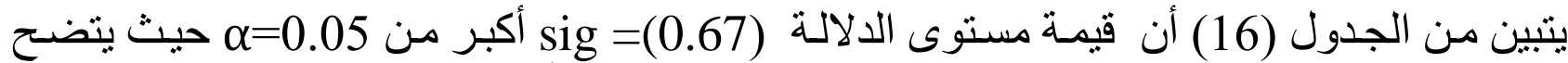

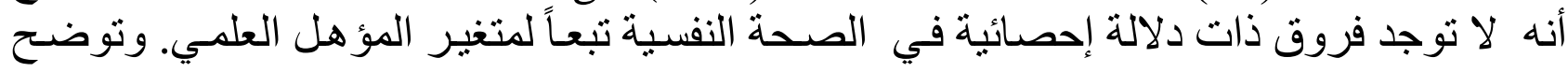

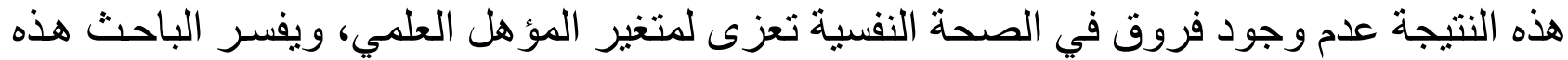

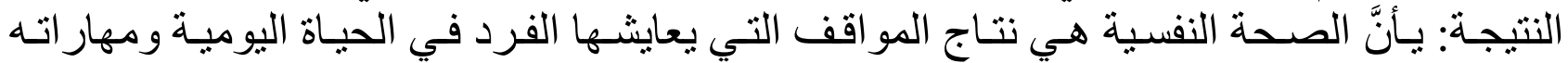

الثخصية التي بتمتع بهان التهان

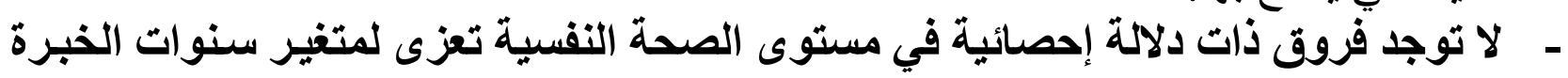

وللتحقق من ذلك تم استخدام تحليل التباين الأحادي لقياس دلالة الفروق بين المجمو عات جدول (17) نتائج تحليل التباين الأحادي One Way ANOVA تبعاً إلى متغير سنو ات الخبرة

\begin{tabular}{|c|c|c|c|c|c|c|}
\hline مستوي الدلالة & قيمة F & المربعات & الحرجية & المربعات & مصدر التباين & المجالات \\
\hline \multirow{3}{*}{0.3} & \multirow{3}{*}{1.21} & 0.238 & 2 & 0.48 & بين المجمو عات & \multirow[t]{3}{*}{ التكيف } \\
\hline & & \multirow{2}{*}{0.197} & 97 & 19.1 & داخل المجمو عات & \\
\hline & & & 99 & 19.6 & المجموع & \\
\hline \multirow{3}{*}{0.3} & \multirow{3}{*}{1.36} & 0.284 & 2 & 0.57 & بين المجمو عات & \multirow[t]{3}{*}{ الإيجابية } \\
\hline & & \multirow{2}{*}{0.209} & 97 & 20.3 & داخل المجمو عات & \\
\hline & & & 99 & 20.8 & المجموع & \\
\hline \multirow{3}{*}{0.5} & \multirow{3}{*}{0.8} & 0.161 & 2 & 0.32 & بين المجمو عات & \multirow[t]{3}{*}{ تحقيق الذات } \\
\hline & & \multirow{2}{*}{0.202} & 97 & 19.6 & داخل المجمو عات & \\
\hline & & & 99 & 19.9 & المجموع & \\
\hline \multirow{3}{*}{0.5} & \multirow{3}{*}{0.7} & 0.098 & 2 & 0.2 & بين المجمو عات & \multirow{3}{*}{ بعد الدين } \\
\hline & & \multirow{2}{*}{0.139} & 97 & 13.5 & داخل المجمو عات & \\
\hline & & & 99 & 13.7 & المجموع & \\
\hline \multirow[b]{3}{*}{0.4} & \multirow[b]{3}{*}{0.91} & 0.085 & 2 & 0.17 & بين المجمو عات & \multirow[t]{3}{*}{ الرجة الكلية } \\
\hline & & 0.093 & 97 & 8.99 & داخل المجمو عات & \\
\hline & & 0.238 & 99 & 9.16 & المجموع & \\
\hline
\end{tabular}

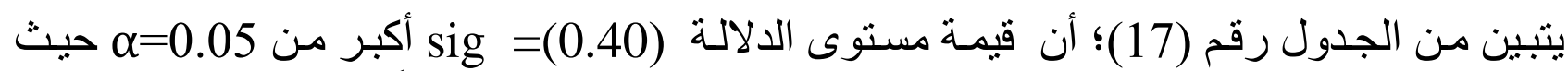

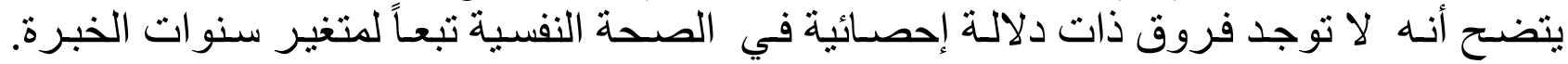

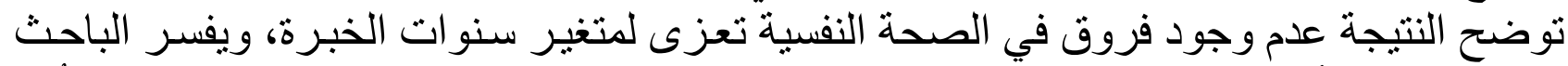

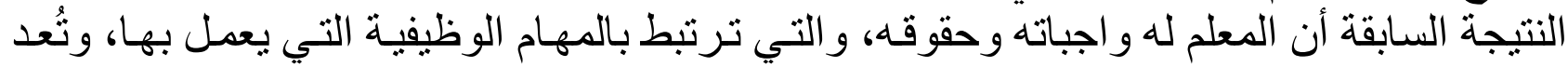
الصحة النفسية نتاج تفاعل الفرد مع البيئة وفق سماته الثئه الثخصية.

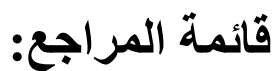

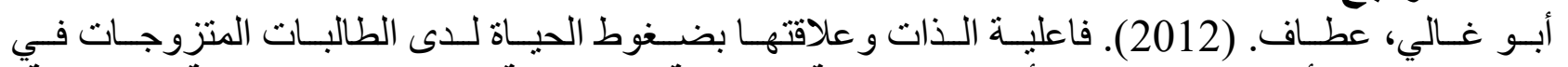

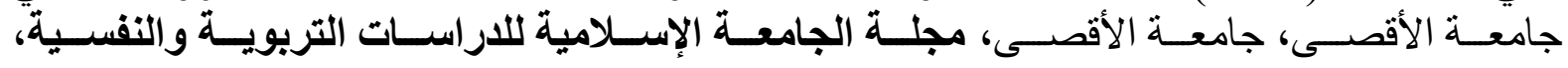




$$
\text { فلسطين، } 20 \text { (1): } 619 \text {-654. }
$$

الأسود، الزهرة (2019). مستوى الصحة النفسية لاى طلبة جامعة الو ادي، دراسـات، جامعة عمـار ثليجي

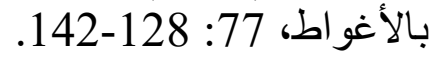

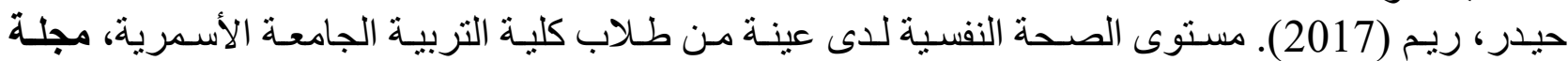

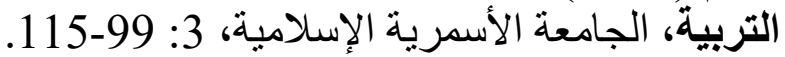

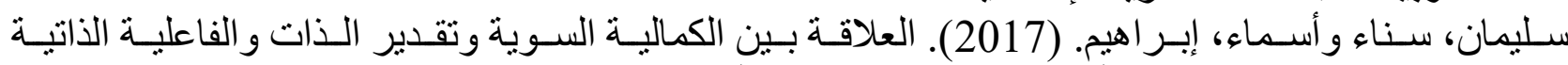

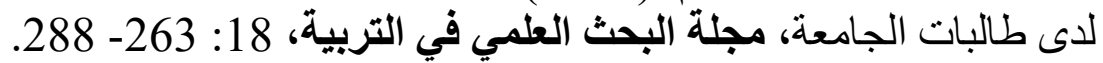

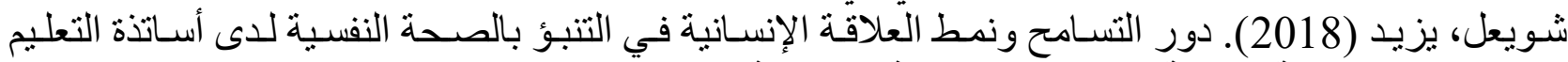
الثانوي، مجلة الحكمة للاراسات التربوية والنفسية، مؤسسة كنوز الحكمة للنشر و التوزيع، 15: 200215 الطيب، فايزة (2016). الصحة النفسية وعلاقتها ببعض سمات الثخصية لاى أولياء أمور الأطفال المعاقين عقلياً، رسالة ماجستير غير منشورة، جامعة أم درمان الإنسان الإسلامية، السودان.

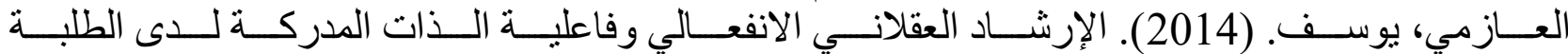

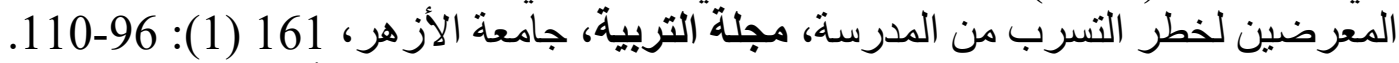

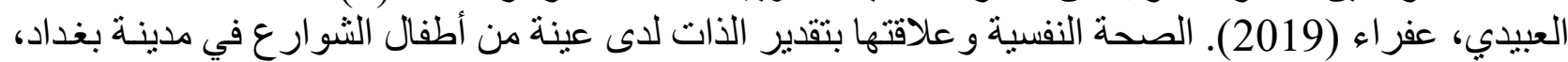

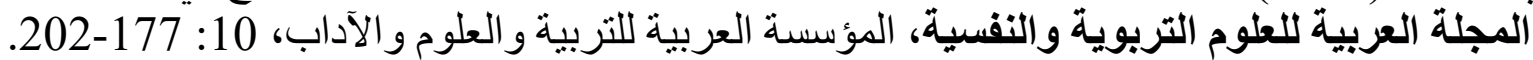

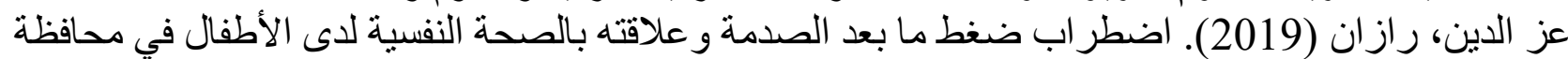

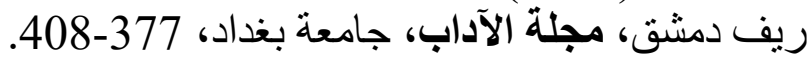

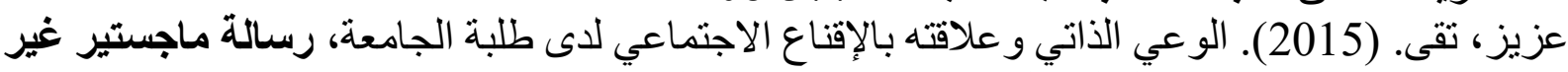

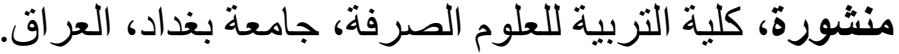

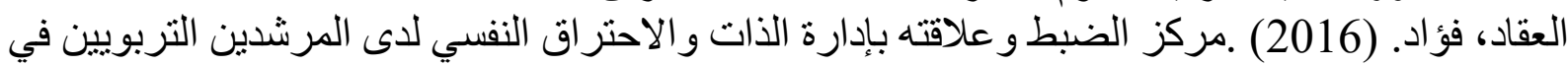

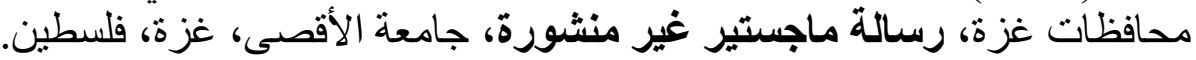

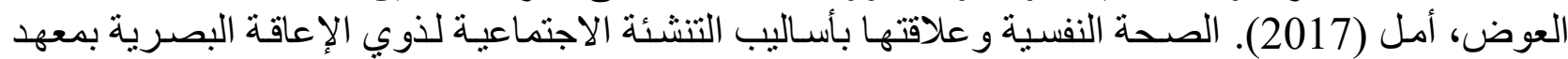

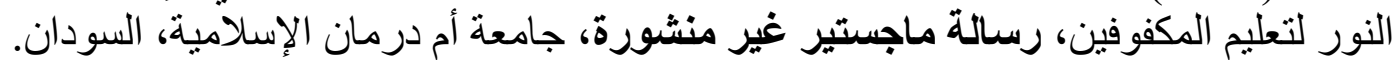

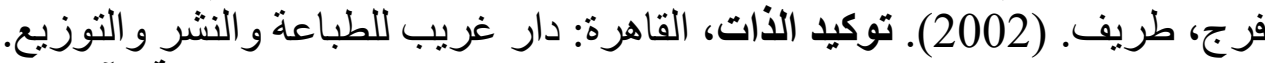

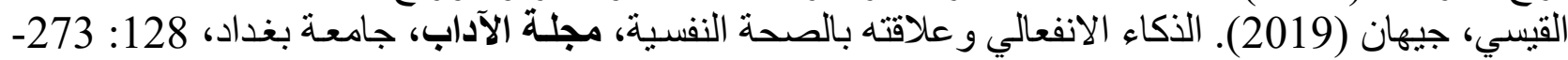
306

الكيال، مختار و علي، أحمد وطاحون، حسين. (2018). الثفقة بالذات و علاقتها بفاعلية الذات لدى طلاب

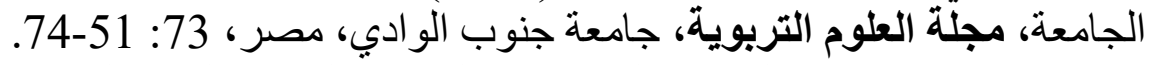

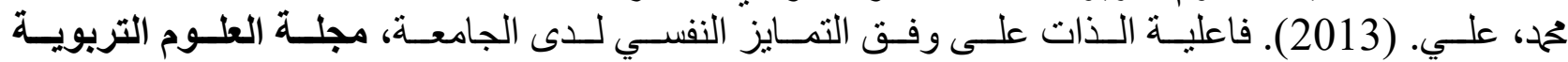

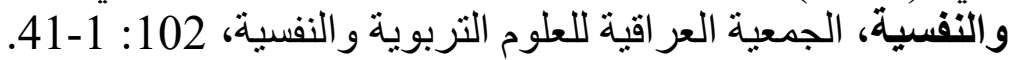

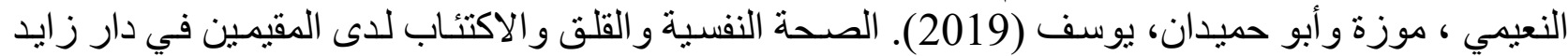
اللر عاية الأسرية في دولة الإمار ات العربية المتحدة، شئون اجتماعية، جمعية الاجتمـاعيين في الثـارقة، 125-95: 36 (142) 36

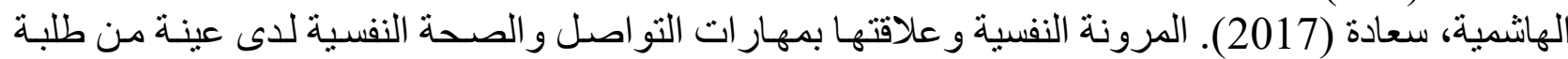

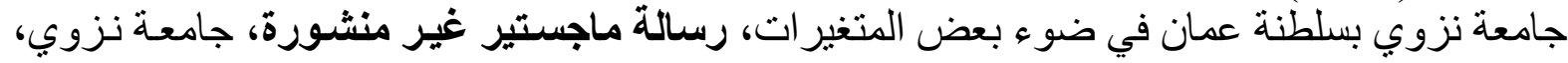
سلطنة عمان.

\section{ARABIC REFERENCES IN ROMAN ALPHABET}

'Abu Ghali, Eataf. (2012). Faeiliat Aldhdhat Waealaqatuha Bidughut Alhayat Ladaa Altaalibat Almutazawijat fi Jamieat Al'aqsaa, Jamieat Al'aqsaa, Majalat Aljamieat Al'iislamiat Lildirasat Altarbawiat Walnafsiati, Filastin, 20 (1): $619-654$.

Al'uswud, Alzahra (2019). Mustawaa Alsihat Alnafsiat Ladaa Tlbt Jamieat Alwadi, Dirasat, Jamieat Eammar 
Thiliji Bial'aghwat, 77: 128-142.

Hayadr, Rim (2017). Mustawaa Alsihat Alnafsiat Ladaa Eayinat min Tullab Kuliyat Altarbiat Aljamieat Al'asmariati, Majalat Altarbiati, Aljamieat Al'asmariat Al'iislamiat, 3: 99-115. Sulayman, Sana' Wa'asma', 'librahim. (2017).

Alealaqat Bayn Alkimaliat Alsawiyat Wataqdir Aldhdhat Walfaeiliat Aldhdhatiat Ladaa Talibat Aljamieati, Majalat Albahth Aleilmii fi Altarbiati, 18: 263- 288.

Shuyael, Yazid (2018). Dawr Altasamuh Wanamati Alealaqat Al'iinsaniat fi Altanabuw Bialsihat Alnafsiat Ladaa 'Asatidhat Altaelim Althaanawii, Majalat Alhikmat Lildirasat Altarbawiat Walnafsiati, Muasasat Kunuz Alhikmat Lilnashr Waltawziei, 15: 200-215.

Altiyb, Fayz (2016). Alsihat Alnafsiat Waealaqatuha Bibaed Simat Alshakhsiat Ladaa 'Awlia' 'Umur Al'atfal Almueaqin Eqlyaan, Risalat Majsatayr Ghyr Manshurat, Jamieat 'Am Darman Al'iislamiat, Alsuwdan.

Aleazimi, Yusf. (2014). Al'iirshad Aleuqlaniu Alainfiealia Wafaeiliat Aldhdhat Almadrakat Ladaa Altalabat Almuearadin Likhatar Altasarub min Almudrasati, Majalat Altarbiat, Jamieat Al'uzhir, 161 (1): 96-110.

Aleabidi, Eifra' (2019). Alsihat Alnafsiat Waealaqatuha Bitaqdir Aldhdhat Ladaa Eayinat min 'Atfal Alshawarie fi Madinat Baghdada, Almajalat Alearabiat Lileulum Altarbawiat Walnafsiati, Almuasasat Alearabiat Liltarbiat Waleulum Waladabi, 10: 177-202.

Eaz Aldiyn, Razan (2019). Aidtirab Daght Ma Baed Alsadmat Waealaqatih Bialsihat Alnafsiat Ladaa Al'atfal fi Muhafazat Rayf Damashqa, Majalat Aladab, Jamieat Bighdad, 377-408.

Eaziz, Taqaa. (2015). Alwaey Aldhdhatia Waealaqatuh Bial'iiqnae Alaijtimaeii Ladaa Tlbt Aljamieati, Risalat Majsatayr Ghyr Manshurati, Kuliyat Altarbiat Lileulum Alsurfati, Jamieat Baghdad, Aleiraq.

Aleaqad, fuaad. (2016) .markaz aldabt waealaqatuh bi'iidarat aldhdhat walaihtiraq alnafsii ladaa almurshadin altarbuiiyn fi muhafazat ghazati, risalat majstayr ghyr manshurat, jamieat al'aqsaa, ghazat, filastin.

Aleawdu, 'amal (2017). alsihat alnafsiat waealaqatuha bi'asalib altanshiat alaijtimaeiat lidhawii al'iieaqat albasriat bimaehad alnuwr litaelim almakfufina, risalat majsatayr ghyr manshurat, jamieat 'am darman al'iislamiat, alsuwdan.

Faraj, tarif. (2002). tawkid aldhaati, alqahirat: dar ghurayb liltabaeat walnashr waltawzie.

Alqisi, jihan (2019). aldhika' alainfiealiu waealaqath bialsihat alnafsiati, majalat aladabi, jamieat baghdad, 128: 273-306.

Alkiali, mukhtar waeali, 'ahmad watahun, husyn. (2018). alshufqat bialdhdhat waealaqatuha bifaeiliat aldhdhat ladaa tullab aljamieati, majalat aleulum altarbawiati, jamieat janub alwadi, misr, 73: 51-74.

Muhmad, eali. (2013). faeiliat aldhdhat ealaa wfq altamayuz alnafsii ladaa aljamieati, majalat aleulum altarbawiat walnafsiati, aljameiat aleiraqiat lileulum altarbawiat walnafsiati, 102: 1-41.

Alnueaymiu , mawzat wa'abu hamidan, yusif (2019). alsihat alnafsiat walqulaq walaiktiaab ladaa almuqimin fi dar zayid lilrieayat al'asriat fi dawlat al'iimarat alearabiat almutahidati, shiuwn aijtimaeiatin, jameiat alaijtimaeiiyn fi alshaariqat, 36 (142): 95-125.

Alhashmiati, saeada (2017). almurunat alnafsiat waealaqatuha bimiharat altawasul walsihat alnafsiat ladaa eayinat min tlbt jamieat nazwiin bisiltanat eamman fi daw' bed almutaghayirati, risalat majsatayr ghyr manshurat, jamieat nazwi, saltanat eaman.

\section{REFERENCE LIST}

Bandura, A.(2001).Social cognitive an argentic Perspective ,Asian ,Journal Social Psychology,2(1)

Mostafaei, A., Ghaderi,D. \& Mohammadkhani,M. (2016). Predicting the Mental Health Based on Attachment Styles in High School Students. Biosciences biotechnology research Asia, 13(3), 1773-1778.

Zulkosky, K (2009). Self-Efficacy: A Concept Analysis, Nursing Forum, 44 (2): 93-102s 